Declarations of interests: none

\section{*Corresponding author:}

Guillem Corbera

National Oceanography Centre,

22 European Way,

33 Southampton SO14 3ZH,

24 United Kingdom

5 Ph. +447522432204

26 E-mail: gc8g14@soton.ac.uk

\author{
Guillem Corberaa,", Claudio Lo Iacono $^{a}$, Eulàlia Gràcia ${ }^{\mathrm{b}}$, Jordi Grinyób, Martina \\ Southampton SO14 3ZH, UK. \\ b. Institut de Ciències del Mar (CSIC), Pg. Marítim de la Barceloneta 37-49, 08003 Barcelona, Spain. \\ c. Istituto di Geologia Ambientale e Geoingegneria (CNR-IGAG), UOS Roma, Piazzale Aldo Moro, 5, 00185, \\ Rome, Italy. \\ d. Oceana, Gran Via 59, 28013, Madrid, Spain.
}

\title{
Ecological characterisation of a Mediterranean cold-water coral reef: Cabliers Coral Mound Province (Alboran Sea, western Mediterranean)
}

University of Southampton Waterfront Campus, 
Scleractinian cold-water coral (CWC) reefs are key habitats for benthic fauna as they enhance spatial heterogeneity and biodiversity. Understanding their environmental and ecological dynamics has therefore important implications for biodiversity conservation. This is especially true for the Mediterranean Sea, where living cold-water coral reefs are rare. In this study, we present a quantitative analysis of the CWC assemblages from Cabliers Coral Mound Province, located in the Alboran Sea (westernmost Mediterranean). The province extends for $25 \mathrm{~km}$, with some mounds rising up to $140 \mathrm{~m}$ from the surrounding seafloor and being partly topped by living CWC reefs. The observed megabenthic species were quantified through video analysis of three Remotely Operated Vehicle (ROV) dives (280 - $485 \mathrm{~m}$ water depth) and their distribution was related to mound geomorphic characteristics and seafloor terrain parameters, extracted from a high-resolution Autonomous Underwater Vehicle (AUV) multi-beam bathymetry. The pronounced abundance and size of scleractinian CWCs among the observed assemblages, makes Cabliers the only known coral mound province in the Mediterranean Sea with currently growing reefs. Within these reefs, several recruits and juveniles of the sebastid Helicolenus dactylopterus were observed, confirming the use of such habitats as nursery grounds by some commercially valuable fish species. The qualitative comparison between the fauna of Cabliers and Atlantic coral mounds suggest that the number of species associated with CWC mounds worldwide is even higher than previously thought. This finding has important implications for the conservation and management of CWC habitats in different geographic regions.

Keywords: cold-water corals, coral reefs, benthic communities, AUV, ROV, nursery grounds

Regional Terms: western Mediterranean Sea, Alboran Sea, Cabliers Coral Mound Province 


\section{INTRODUCTION}

Over the last decade, the study of deep-sea benthic communities through Remotely Operated Vehicle (ROV) inspections has constantly expanded, largely due to ongoing technological improvements that have made ROV operating costs more affordable (Marsh et al., 2012; Neves et al., 2014; Gori et al., 2017; Khripounoff et al., 2017). Consequently, marine scientists have been able to describe a vast range of new deep-sea ecosystems and to characterise in more detail those that were already known to science (Roberts et al., 2006; Khripounoff et al., 2017; Bo et al., 2018). However, most of these studies are based on punctual observations, which inhibits to highlight the spatial distribution and ecological role of many benthic habitats and species at a regional scale. In parallel with ROV development, marine acoustics and Autonomous Underwater Vehicles (AUV) have also experienced significant technological advances and currently allow researchers to characterise the seafloor morphology at a metric scale (e.g. 1-2 $\mathrm{m}^{2}$ pixel size; Huvenne et al., 2011; Wynn et al., 2014; Rona et al., 2015; Fabri et al., 2017). Therefore, combining ROV video-footage and AUV high-resolution multi-beam data allows for a detailed characterisation of benthic communities and helps to understand their spatial correlation with fine-scale seafloor geomorphology.

Among deep-sea benthic assemblages, cold-water corals are generally the focus of the research efforts from the scientific community, as they generate key habitats for benthic fauna (Freiwald et al., 2004; Roberts et al., 2006; Buhl-Mortensen et al., 2010). Several recent studies focused on the distribution of non-scleractinian cold-water corals, such as anthipatarians and octocorals (Fabri and Pedel 2012; Tong et al., 2012; Bullimore et al., 2013; Bo et al., 2014a, b; Grinyó et al., 2016, 2018; Pierdomenico et al., 2018). Nevertheless, stony (i.e. scleractinian) cold-water corals (hereafter mentioned as CWC) such as Lophelia pertusa and Madrepora oculata have become some of the most intensively studied species in the last decade (Freiwald et al., 2004; Roberts et al., 2009b; Huvenne et al., 2011; Mienis et al., 2014; Buhl-Mortensen et al., 2017; Lim et al., 2017; Lo Iacono et al., 2018a). CWC are solitary or colonial organisms that generally occur in areas characterised by hard substrata on which they can settle and that can form dense benthic assemblages across a depth range of $39 \mathrm{~m}$ (Norwegian fjords) to $2000 \mathrm{~m}$ (NW Mediterranean canyons) (Freiwald et al., 2004; Roberts et al., 2006; Lo Iacono et al., 2018b; Sartoretto and Zibrowius, 2018). Hard substrata are usually located on complex geomorphic features such as submarine canyons, seamounts, shelf edges and landslides, where enhanced food-rich bottom currents provide suitable environmental conditions for CWC settlement and growth (Orejas et al., 2009; Davies et al., 2009; Huvenne et al., 2011; Mienis et al., 2012; Lo 
Iacono et al., 2012, 2014, 2018a). CWC have a worldwide distribution, but historically, their assemblages have been more extensively studied along the North Atlantic continental margins (Hovland and Risk, 2003; Kano et al., 2007; De Mol et al., 2011; Mazzini et al., 2012). Among the framework-building CWCs, L. pertusa is the most widespread and abundant species, followed by $M$. oculata, which is more abundant in warmer waters such as the Mediterranean Sea (Savini and Corselli 2010; Fabri et al., 2014; Taviani et al., 2017) and Solenosmilia variablis, more common in the South Pacific Ocean (Koslow et al., 2001; Tresher et al., 2014). The spatial distribution of these species is not only controlled by the availability of suitable substrata but also by a complex interplay of many environmental factors such as temperature, salinity, $\mathrm{pH}$, dissolved oxygen, sedimentation rates, current intensity and food supply (Dodds et al 2007; Davies et al., 2009; Maier et al., 2009; Duineveld et al., 2012; Naumann et al., 2014). Framework-building CWC generally grow in waters with temperatures between 3 and $16^{\circ} \mathrm{C}$ (Rogers, 1999, Davies and Guinotte, 2011) and salinity of 34-37 psu (Dullo et al., 2008). They are linked to high surface productivity and average bottom current speeds between 8 and $15 \mathrm{~cm} \mathrm{~s}^{-1}$ (Duineveld et al., 2012; Mienis et al., 2012).

Under persistent suitable environmental conditions, living framework-building CWCs can form dense reefs extending over hundreds of meters and rising up to a few meters above the surrounding seafloor (Mortensen et al., 2001; Lo Iacono et al., 2018b). Over longer timespans and by baffling sediments within the coral framework, these living reefs might develop into three-dimensional geomorphological features, known as coral mounds (Wienberg and Titschack, 2018). These mounds can vary in shape and reach heights of up to $380 \mathrm{~m}$ depending on their development stage (Kano et al., 2007; Mienis et al., 2007; Van Rooij et al., 2009; De Mol et al., 2011; Hebbeln et al., 2014; Buhl-Mortensen et al., 2017).

CWC reefs present a higher habitat complexity and heterogeneity than the surrounding seafloor, which allows for an increase in the number of available ecological niches (Jones et al., 1994; Buhl-Mortensen et al., 2010). These habitats may also act as shelter and nursery grounds for many benthic species that use the coral framework to hide from predators (Costello et al., 2005). Because of all the above mentioned ecological benefits provided, CWC reefs are considered biodiversity hotspots, with a biological richness comparable to that of shallowwater tropical reefs (Roberts et al., 2006; Buhl-Mortensen et al., 2010). Species richness in $L$. pertusa reefs is probably the highest within CWC, with more than 1300 associated species (Roberts et al., 2006). However, not all CWC reefs and mounds share the same fauna. Considerable differences in species composition have been observed between Norwegian and 
127 African coral mound assemblages, which are dominated by L. pertusa (Buhl-Mortensen et al., 2017).

129 Due to their uniqueness, functional role and susceptibility to anthropogenic disturbances (Fosså et al., 2002; Althaus et al., 2009), framework-building CWC assemblages are considered vulnerable marine ecosystems (FAO, 2009). The OSPAR Commission and the General Fisheries Commission for the Mediterranean (GFCM) also count these assemblages within the lists of sensitive and threatened marine habitats that require protection (OSPAR, 2008; GFCM, 2009). Therefore, understanding the environmental constraints and ecological interactions of these assemblages, has important implications for the determination of their spatial distribution and thus, diversity conservation. This is especially true for the Mediterranean Sea where living CWC reefs are very limited compared to the North Atlantic (Freiwald et al., 2004; Vertino et al., 2010; Lo Iacono et al., 2018b,c). Framework-building CWCs in the Mediterranean are generally represented by small populations or scattered colonies, mainly located in submarine canyons and on landslides (Orejas et al., 2009; Savini and Corselli, 2010; Vertino et al., 2010; Gori et al., 2013; Lastras et al., 2016; Fabri et al., 2014; Fanelli et al., 2017; Taviani et al., 2017).

Within the Mediterranean basin, coral mound clusters are mainly located in the Ionian Sea (Savini and Corselli, 2010), Tyrrhenian Sea (Remia and Taviani, 2005) and the Alboran Sea (Comas and Pinheiro, 2010; Lo Iacono et al., 2014). However, they are generally buried beneath meters of sediments or in a stage of decline (Hebbeln et al., 2009; Comas and Pinheiro, 2010; Lo Iacono et al., 2012; Lo Iacono et al., 2014). An exception to this general observation are the coral-topped mounds located off Santa Maria di Leuca, Italy, where dense aggregations of L. pertusa and M. oculata have been observed growing on landslide blocks (Taviani et al., 2005; Vertino et al., 2010; Savini et al., 2016) and supporting a high biodiversity (Mastrototaro et al., 2010). Observations of living CWC have also been reported from two mound clusters in the Alboran Sea: the West Melilla Mounds (Lo Iacono et al., 2014) and the East Melilla Mounds (Comas and Pinheiro, 2010; Fink et al., 2013). Nevertheless, they only harbour small isolated colonies of L. pertusa or M. oculata and they are mostly covered by dense aggregations of non-scleractinian corals, sponges and echinoderms (Fink et al., 2013; Hebbeln and Wienberg, 2016; Lo Iacono et al., 2018b). Furthermore, none of these studies present a quantitative analysis of the megabenthic fauna inhabiting the coral mounds of the Alboran Sea. The same paucity of studies applies to the rest of the Mediterranean Sea, where only Mastrototaro et al. (2010) qualitatively characterised the fauna associated to Santa Maria di Leuca coral-topped mounds. Therefore, there is a knowledge gap regarding the relative 
abundance of taxa associated to CWC reefs in the Mediterranean Sea. The absence of quantitative data is limiting the creation of solid baselines required to better understand these sensitive ecosystems, which would help towards a more appropriate conservation and management measures.

In the Alboran Sea, north-east of the East Melilla Mounds, the recently surveyed Cabliers Coral Mounds present thriving CWC assemblages growing on some of their crests (Lo Iacono et al., 2016; Corbera et al., 2017). Cabliers is a coral mound province extending NE-SW for $25 \mathrm{~km}$ (Fig. 1) and developing on a volcanic outcrop known as Cabliers Bank (Würtz et al., 2015) in a water depth range of $250-710 \mathrm{~m}$. In order to contribute to increase the knowledge of CWC reefs in the Mediterranean Sea, this study aims to quantitatively describe for the first time the assemblages found on the Cabliers Coral Mounds. It also attempts to provide a detailed quantification of density and distribution of the main associated species, addressing a knowledge gap on a regional/basin scale. Specifically, we will:

- Determine the abundance, size and distribution of CWC and the most conspicuous associated taxa.

- Determine which are the main megabenthic assemblages occurring on the Cabliers Coral Mounds

- Reveal which are the most important seafloor features driving the distribution of the species

- Perform a qualitative comparison between the fauna found on these Mediterranean CWC mounds and the one observed on analogous structures of the Mediterranean Sea and the Atlantic.

\section{Geological and oceanographic characteristics of the Alboran Sea}

The Alboran Sea (AS) is a marginal sea located at the westernmost Mediterranean Sea, enclosed between the Iberian Peninsula (South Spain) and North Africa (North Morocco and Algeria) (Fig. 1B). This basin is bound by the Strait of Gibraltar to the west, by the Cabo de Gata to the northeast, and by Cap Figalo to the southeast (Fig. 1). The AS includes three main sub-basins (i.e. West, East and South Alboran Basins) separated by the Alboran Ridge (Fig. 1). 


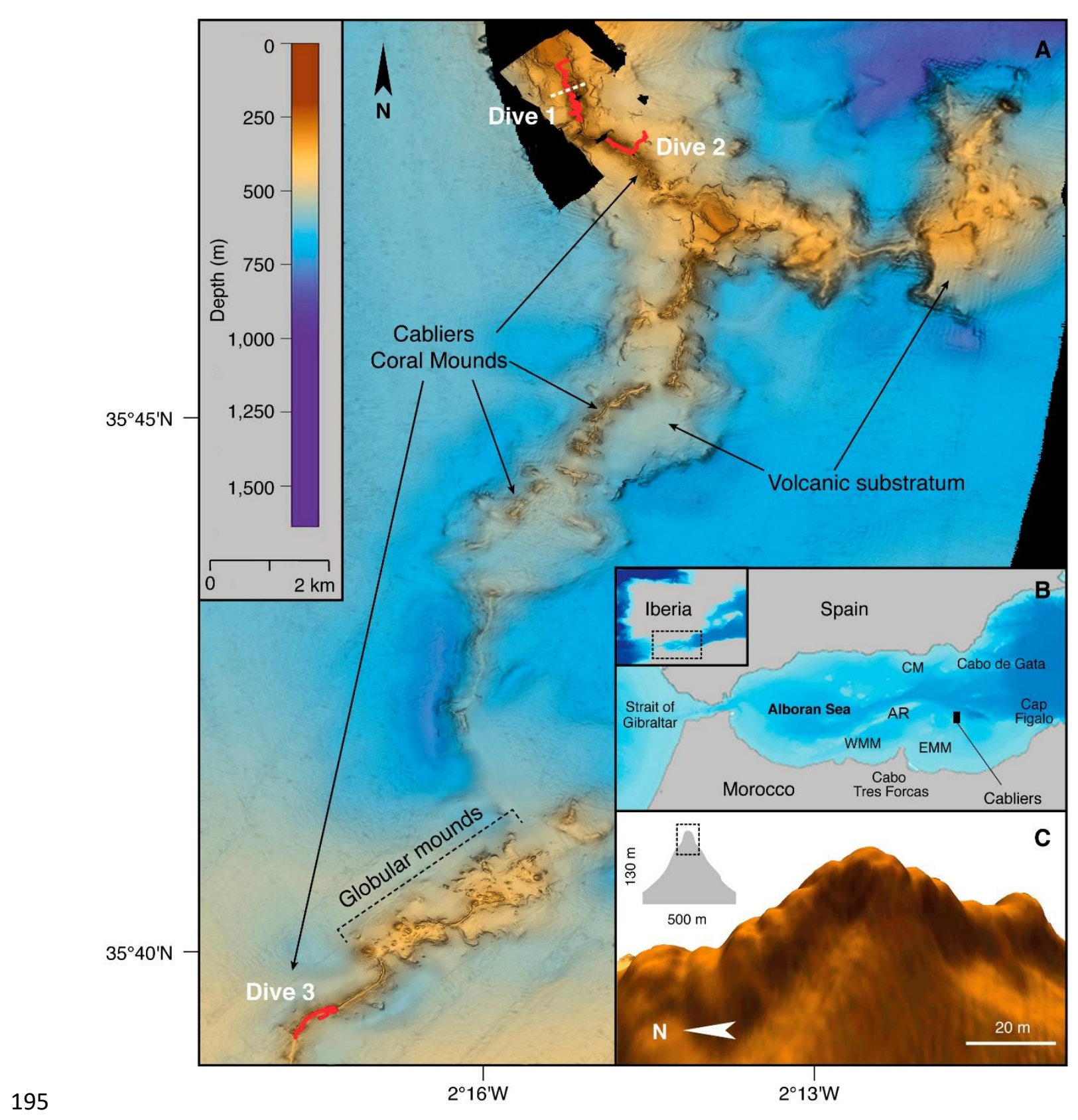

Figure 1. Bathymetric map of the IdefX AUV multi-beam bathymetry ( $2 \mathrm{~m}$ resolution) along the Cabliers Coral Mounds overlapped on shipboard bathymetry of the region (20 m resolution) (A). Inset of the Alboran Sea, the black rectangle indicates the location of the Cabliers Coral Mound Province (B). Threedimensional representation of the mini-mounds occurring on the crest of the Cabliers Coral Mounds (C). The red lines on (A) indicate the path of the three Max-Rover ROV dives; the white dashed line indicates the location of the transversal mound section observed on (C). AR: Alboran Ridge, CM: Chella Mound, WMM: West Melilla Mounds, EMM: East Melilla Mounds.

197 The seafloor geomorphology of this basin is relatively complex, displaying long ridges and several seamounts that have been carefully mapped in the frame of successive high-resolution bathymetric cruises (e.g. Gràcia et al., 2006, 2012; Lo Iacono et al., 2008). These features are 
intrinsically associated to the recent tectonic evolution of the basin and thus, related to the subducting slab located at the West Alboran Basin (Spakman et al., 2018).

The different tectonics domains are defined by large active strike-slip faults, such as the AlIdrissi Fault System (FS) (Gràcia et al., 2006, 2012); Carboneras FS (Moreno et al., 2016), Averroes-Yusuf FS (Perea et al., 2017), as well as the prominent thrust-fault Alboran Ridge FS (Gómez de la Peña et al., 2018). In consequence, the Alboran Sea is a seismically active area, where moderate to large earthquakes have occurred in the past and recent times (Gràcia et al., 2012; Grevemeyer et al., 2015).

The water mass circulation in the AS is characterised by the interaction between Atlantic and Mediterranean water masses, which create a regional thermohaline circulation (Garcia Lafuente et al., 1998). Atlantic warmer and less saline waters (S 36.2 psu, T 15 ${ }^{\circ} \mathrm{C}$ ) enter the AS through the Strait of Gibraltar and flow within the first 150-200 $\mathrm{m}$ of the water column at a velocity of $\sim 50-100 \mathrm{~cm} \cdot \mathrm{s}^{-1}$ (Garcia Lafuente et al., 1998; Oguz et al., 2014). The denser, colder and slower Mediterranean waters (S 38.4 psu, T 13.5 ${ }^{\circ} \mathrm{C}$ ) flow deeper and head out of the Mediterranean Sea at $\sim 10 \mathrm{~cm} \cdot \mathrm{s}^{-1}$ (Garcia Lafuente et al., 1998). The circulation of the Atlantic waters (AW) is mainly driven by two semi-permanent anticyclonic gyres (western and eastern Alboran Gyres) (Millot, 1999). After entering the Strait of Gibraltar, the AW is dragged towards the Spanish coast by the Western Alboran Gyre and then moves towards the African coast, where it meets the Eastern Alboran Gyre that brings the AW from Melilla to the Cabo de Gata (South Spain) (Millot, 1999). In contrast, the deeper Mediterranean Water, named Levantine Intermediate Water (LIW), flows in the opposite direction but without any effect from the surface gyres. The latter water mass forms in the Eastern Mediterranean basin and travels towards the AS, crossing the Western Mediterranean Basin.

Three coral mound clusters have been reported in the AS: the Chella Mound (Lo Iacono et al., 2018b), the West Melilla Mounds (Lo Iacono et al., 2014) and the East Melilla Mounds (Comas and Pinheiro, 2010; Fink et al., 2013). The Chella Mound is located off the Almeria coast, it presents a ridge-like mound that raises $15-70 \mathrm{~m}$ from the surrounding seafloor and extends for a maximum of $3.4 \mathrm{~km}$ (Lo Iacono et al., 2018b). The West and East Melilla Mounds are located off the coast of Cabo Tres Forcas, on the southern margin of the AS. The western mounds are smaller (1-48 m tall) and buried by fine sediments (Lo Iacono et al., 2014). On the other hand, the East Melilla Mounds are ridge-like features that can extend for up to $6 \mathrm{~km}$ and rise 20-60 $\mathrm{m}$ from the seafloor (Comas and Pinheiro, 2010).

In this physiographic and oceanographic setting, the Cabliers Coral Mound Province is located northeast of the Cape Tres Forcas and the East Melilla Mounds. 


\section{MATERIAL and METHODS}

\subsection{Data acquisition and processing}

Three ROV dives and a high-resolution AUV multi-beam bathymetric survey were performed on the Cabliers Coral Mounds during the SHAKE cruise, conducted on board the R/V Sarmiento de Gamboa in April-May 2015. Seafloor video transects were recorded by means of the ROV Max-Rover (Hellenic Centre of Marine Research - Greece), equipped with an HD video camera (1920x1080 pixels), a manipulator arm and two parallel laser beams, $10 \mathrm{~cm}$ apart. During the collection of the video transects, ROV positioning was estimated by means of an ultra-short baseline (USBL) transponder mounted on the vehicle, which gave a geographic position every 3 seconds approximately. The ROV tracks were projected to UTM using the Geographic Information System ArcGIS 10.3.1 (ArcGIS Development Team, 2015) and all outlier points of the navigation data were removed to obtain a smooth plot of the geo-referenced transect. Outliers were identified as points located at a distance away from the main path that the ROV could not have reached, even at its maximum speed $\left(0.6 \mathrm{~m} \mathrm{~s}^{-1}\right)$. These outliers are usually the consequence of signal beam reflections on seafloor features. The total distance covered by the ROV dives across the mounds was $5.2 \mathrm{~km}$. Dive 1 and 2 were recorded at the northern part of Cabliers, whereas Dive 3 was performed at the southernmost part. All transects covered sectors of both crest and flanks of the coral mounds (Fig. 1). The three dives were performed in water depths between 280 and $485 \mathrm{~m}$ and the length of the video-transects ranged from 1249 to $2516 \mathrm{~m}$ (Table 1). During the ROV dives, both biological and rock samples were acquired by means of the ROV mechanical arm. These samples were later used to help in faunal identification and bedrock characterisation.

Table 1. Geographical coordinates, depth and length for each of the ROV dives analysed in this study.

\begin{tabular}{|c|c|c|c|c|c|}
\hline \multirow[t]{2}{*}{ Dive } & \multirow[t]{2}{*}{ Date } & \multicolumn{2}{|c|}{ Position } & \multirow{2}{*}{$\begin{array}{c}\text { Depth range } \\
(\mathrm{m})\end{array}$} & \multirow{2}{*}{$\begin{array}{l}\text { Length } \\
\text { (m) }\end{array}$} \\
\hline & & Start & End & & \\
\hline 1 & $21 / 05 / 2015$ & $\begin{array}{c}35^{\circ} 48^{\prime} 18^{\prime \prime} \mathrm{N}, \\
2^{\circ} 15^{\prime} 17^{\prime \prime} \mathrm{W} \\
35^{\circ} 47^{\prime} 39^{\prime \prime} \mathrm{N},\end{array}$ & $\begin{array}{c}35^{\circ} 47^{\prime} 55^{\prime \prime} \mathrm{N}, \\
2^{\circ} 15^{\prime} 13^{\prime \prime} \mathrm{W} \\
35^{\circ} 47^{\prime} 34^{\prime \prime} \mathrm{N},\end{array}$ & $283-380$ & 2516 \\
\hline 2 & $22 / 05 / 2015$ & $\begin{array}{c}2^{\circ} 14^{\prime} 35^{\prime \prime} \mathrm{W} \\
35^{\circ} 39^{\prime} 19^{\prime \prime} \mathrm{N},\end{array}$ & $\begin{array}{c}2^{\circ} 14^{\prime} 55^{\prime \prime} \mathrm{W} \\
35^{\circ} 39^{\prime} 29^{\prime \prime} \mathrm{N},\end{array}$ & $294-444$ & 1250 \\
\hline 3 & $21 / 05 / 2015$ & $2^{\circ} 17^{\prime} 47^{\prime \prime} \mathrm{W}$ & $2^{\circ} 17^{\prime} 34^{\prime \prime} \mathrm{W}$ & $418-486$ & 1401 \\
\hline
\end{tabular}


High-resolution multi-beam bathymetric data were acquired by means of an EM2040 Kongsberg Maritime multi-beam echo sounder $(300 \mathrm{kHz})$, installed on the Autonomous Underwater Vehicle (AUV) IdefX (IFREMER - France). The AUV was programmed to acquire data $70 \mathrm{~m}$ above the seafloor, allowing for a metric-scale bathymetric resolution. The AUV collected the data with inertial navigation. Prior to the start of each survey, a calibration profile across the last $100 \mathrm{~m}$ of the water column was acquired on the flattest seafloor sectors. This calibration was used to calibrate the sound velocity during the multi-beam acquisition and in the post-processing phases.

All the multi-beam data obtained was processed on-board. The AUV navigation was corrected in Caraibes 4.3 by means of the RegBat module using both the bathymetric contours and the USBL as a reference for the correction of the inertial navigation. The data was then imported into CARIS HIPS and SIPS 9.1, where a constant zero value of tide was applied. Finally, spikes and noise were reduced through manual cleaning in areas of line overlap, and a bathymetric grid with a $2 \mathrm{~m}$ cell size was created as final outcome.

\subsection{Video analysis}

Video transects were analysed using the editing software Adobe Premiere Pro CS6, following the methodology described in Gori et al. (2011). Laser points projected by two parallel beams located on the ROV frame, separated $10 \mathrm{~cm}$ from each other, were used to estimate transect width and to measure species size. The field of view slightly varied in relation to the ROV distance from the seafloor, being reduced to $1 \mathrm{~m}$ when the vehicle was close to the seabed.

Due to intermittent malfunctioning of the USBL, the location of the organisms along the ROV track had to be acquired by means of the following procedure. Each video transect was divided into over 30 fragments determined by control points. From one control point to the following one, DVL data was used to determine the course and the track of the ROV. This was thoroughly checked combining ROV video images with AUV High-resolution bathymetry. For each fragment, ROV speed was calculated based on the vehicle's travelled distance and the time interval between the corresponding control points. Such velocities were then used to calculate the position of each observed organism by using the following formula:

$$
x_{t}=x_{i}+v_{i} \cdot\left(t-t_{i}\right)
$$

where $x_{t}$ is the distance from the start of the track at which the organism was identified, $i$ is the analysed fragment, $x_{i}$ is the distance covered by the ROV until the start of the current fragment, 
$v_{i}$ is velocity of the ROV in the current fragment, $t$ is the time when the organism was identified in the video footage and $t_{i}$ is the time at the start of the analysed fragment.

All tracks were edited to remove sections of footage where the ROV was stationary (i.e. collecting samples or recording close-up images). Non-valid sequences such as poor visibility footage, caused by sediment resuspension, or parts where organism identification was not possible due to inappropriate altitude of the ROV (i.e. $>4 \mathrm{~m}$ ) were quantified, isolated and removed from the subsequent statistical analyses.

All megafaunal organisms visible along each transect, within a section of $1 \mathrm{~m}$ around the central point of the field of view, were counted and identified to the lowest, practicable taxonomic level (i.e. typically species). Organisms that were not possible to identify to the species level, were classified within higher taxonomic levels or designated as morphospecies (e.g. "white encrusting sponge"). For the species Phanopathes rigida, which commonly appeared forming dense aggregations, the quantification of single colonies was not always possible. Therefore, this species' abundance was obtained through the quantification of such aggregations (hereafter named as living-patches). Density of CWC colonies (sensu Oliver, 1968) and associated megafauna were calculated by dividing each ROV transect into $2 \mathrm{~m}^{2}$ sampling units (i.e. $2 \mathrm{~m}$ long x $1 \mathrm{~m}$ wide segments). This sampling unit size was chosen in order to quantify the species distribution along the transect at a high resolution. Moreover, the adopted sampling unit already resulted to be adequate for the analysis of deep-sea anthozoan assemblages in the western Mediterranean (Ambroso et al., 2013).

The size of each measurable living colony (sensu Oliver, 1968) of M. oculata and L. pertusa was calculated by means of still images, extracted from HD video footage when the parallel laser beams crossed the colony base. Still images were processed using the image software Macnification 1.8 (Orbicule, Inc.), which allows measurements of coral colonies by drawing a line along the largest diameter of the living coral. The same procedure was carried out to measure the total length of the most abundant fish species, the sebastid Helicolenus dactylopterus. Substratum type was the only environmental variable determined from the ROV footage and was classified into four classes: fine sands with coral rubble (CRFS), coral rubble (CR), dead coral framework with fine sands (CFFS) and dead coral framework (CF) (Fig. S1).

\subsection{Statistical analyses}

The differences in taxonomic composition and diversity amongst the ROV dives were explored via species relative abundance, species richness $(\mathrm{S})$ and Shannon diversity index $\left(\mathrm{H}^{\prime}\right)$ values. 
The distribution of the most relevant and abundant taxa observed in the video transects was then plotted, displaying species density against the bathymetric profile and along the transect length of each dive. All 2582 sampling units were used in density plots, 1253 of them corresponding to Dive 1, 626 to Dive 2 and 703 sampling units to Dive 3.

Regarding CWC size structure, descriptive statistical parameters such as skewness and kurtosis were calculated to determine if the population was dominated by small or large colonies. Both M. oculata and L. pertusa populations, with more than 1000 and 100 colonies respectively, were large enough to perform robust skewness and kurtosis tests. Both tests assume normality as a null hypothesis. Skewness is a measure that gives information about the symmetry of a distribution. A population has an asymmetrical distribution when the skewness is statistically significant $(\mathrm{p}<0.05)$. If skewness is positive, it indicates a higher percentage of small colonies, whereas negative values of skewness relate to a higher proportion of large ones. If skewness values are close to 0 it indicates that the size structure of the colonies is close to a normal distribution. On the other hand, if the kurtosis test is statistically significant $(\mathrm{p}<0.05)$ it means that data distribution has shorter or longer tails than expected for a normal distribution. Skewness and kurtosis were calculated using the functions agostino.test (Komsta and Novomestky, 2012) and anscombe.test (Anscombe and Glynn, 1983) from the moments package of the R software (Komsta and Novomestky, 2012; R core team, 2017). Colony size of M. oculata and L. pertusa was plotted using $10 \mathrm{~cm}$ size classes. M. oculata average size was also plotted against the bathymetric profile and along the transect length in Dive 1, which was the only dive with an abundance high enough to observe size patterns along geomorphologic features. The colony size data from this dive was log-transformed to achieve normality and differences between average size of CWC growing on the flanks and the crest of the mound were assessed by means of a Student's $t$-test. The determination of crest and flank areas was performed through a combination of visual assessment of the footage and the ROV location.

A Spearman rank correlation was used to verify that CWC density increases towards the summit of ridge-like features (hereafter mentioned as mini-mounds) occurring at the crest of the coral mounds. A moving average of period 5 was applied to the CWC density data to exclude small scale variability. This data was then correlated to the values of a fine scale bathymetric position index (BPI) (inner radius: $5 \mathrm{~m}$, outer radius: $10 \mathrm{~m}$ ), which detected most of the mini-mound features on the AUV multi-beam along the Cabliers mounds crest. The BPI is a measure consisting on a second order derivative of the seafloor surface that determines the elevation of each grid cell in relation to the surrounding landscape of the bathymetry. This 
derivative produces a new raster where geomorphological features such as crests, slopes, depressions and flat areas are indicated.

To evaluate the relationships between megafaunal abundance and seafloor features (see below) a canonical correspondence analysis (CCA) was performed. CCA is a multivariate constrained ordination test that attempts to explain the effect of each environmental variable on species distribution (Greenacre and Primiceiro, 2013). Taxa that had an abundance lower than five individuals were not considered in the analysis to avoid noise in the final outputs. Furthermore, off-mound areas (i.e. regions of fine sands and outcropping rock), occurring at the beginning of Dive 1 and 2 were not considered for the assemblage analyses. The CCA was carried out for the three Dives, to identify the composition of the main assemblages occurring on the mound and the seafloor physical characteristics influencing their distribution. The CCA was executed using the $c c a$ function from the vegan package (Oksanen et al., 2013) of the R software (R core team, 2017). This was performed together with the function anova.cca, which runs an ANOVA-like permutation test. This test was used to assess the significance of each seafloor feature and to determine which was the variable that had a greater effect on the distribution of megafaunal species (Chambers and Hastie, 1992). The CCA was performed for sampling unit sizes of 2, 4, 10 and $20 \mathrm{~m}^{2}$ in order to assess how spatial scale affects the determination of benthic assemblages and their corresponding environmental setting.

The environmental variables used in the CCA statistical analysis, included depth and seafloor terrain parameters (i.e. slope, terrain roughness, aspect and bathymetric position index) that were derived from the high-resolution bathymetry using the Add-on RSOBIA (Le Bas, 2016) and Benthic Terrain Modeller (Walbridge et al., 2018) within the Geographic Information System software, ArcGIS 10.3.1 (ArcGIS Development Team, 2015). The roughness raster was obtained using the VRM algorithm (Sappington et al., 2007). In this analysis, the BPI was computed at a broad scale (inner radius: $10 \mathrm{~m}$, outer radius: $20 \mathrm{~m}$ ) to account for large-scale features that can have a greater effect on species distribution. Values of all these seafloor features were obtained from the central point of each sampling unit of the video transects, using the extract function from the raster package within the R software v 3.4.0 (R core team, 2017). Substratum type was also included in the CCA analysis, as four different variables coded for presence absence. The substratum type with the higher cover was assigned to each sampling unit. 


\section{RESULTS}

397

\subsection{Physiography of the Cabliers Coral Mounds}

399

400

The Cabliers Coral Mounds developed over a rocky outcrop, witnessed in the ROV footage and interpreted in the AUV bathymetry. Collected rock samples during Dives one and two helped to determine the substratum as being of volcanic origin. The mounds generally present a ridge-like morphology with an average height of $\sim 77 \mathrm{~m}$ and a maximum of $140 \mathrm{~m}$. Flanks are $35^{\circ}$ steep on average. Overall, the sections of the mounds with a greater relief exhibited wider bases. The high-resolution AUV multi-beam bathymetry revealed that the crests of the mounds consist of a series of consecutive mini-mounds (Fig. 1C). These smaller features, whose internal structure consists of dead coral framework and baffled sediments, can rise up to $7 \mathrm{~m}$ on top of the mound's crest and extend for $23 \mathrm{~m}$ in width. Towards the southern part of the Cabliers, a field of complex globular mounds developed (Fig. 1A); these mounds have an average diameter of $121 \mathrm{~m}$ and rise up to $\sim 40 \mathrm{~m}$ from the surrounding seafloor. This field of globular mounds occupies an area of about $3 \times 1 \mathrm{~km}$. South of this region, Cabliers is again exclusively formed by aligned ridge-like mounds.

\subsection{General Megafaunal Characteristics}

A total of 2582 sampling units $\left(2 \mathrm{~m}^{2}\right)$ were obtained from the ROV dives, in which 7737 organisms representing 49 different taxonomic groups were identified (Table S1). $64.1 \%$ of these organisms, could be identified to species or genus level, whereas $13.1 \%$ were included in broader taxonomic categories, and $22.8 \%$ were considered as morphospecies. The most abundant species was the antipatharian Phanopathes rigida with 1532 colonies, followed by the gorgonian Acanthogorgia hirsuta $(\mathrm{n}=1491)$, and M. oculata $(\mathrm{n}=1160)$. These species represented respectively the $19.6 \%, 18.9 \%$ and $15.5 \%$ of all identified organisms. Other commonly observed species were the sponge Asconema setubalense (12\% of the total) and the antipatharian Parantipathes larix (5\%). 

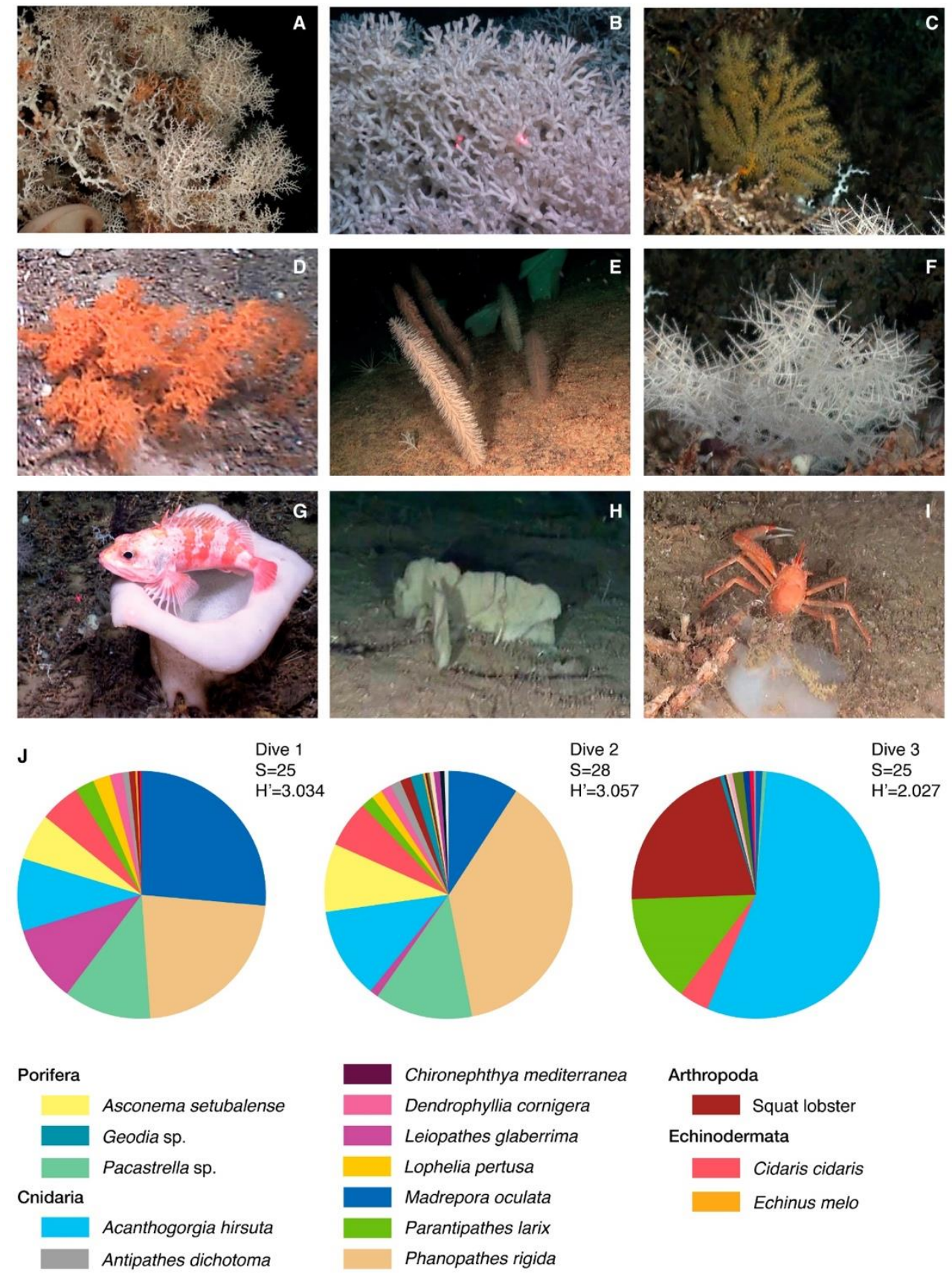

Figure 2. Most abundant fauna observed in the ROV footage (A-I), and (J) species relative abundance, richness (S) and diversity (H') of each dive. Madrepora oculata (A), Lophelia pertusa (B), Acanthogorgia hirsuta (C), Leiopathes glaberrima (D), Parantipathes larix (E), Phanopathes rigida (F), Asconema setubalense (sponge) and Heliconelus dactylopterus (fish) (G), Pacastrella sp. (H), Squat lobster (I). Still images A, C, E, F and H, (C) OCEANA.

\subsubsection{Northern sector - Dives 1 and 2}

429 The seafloor observed on the two northern dives, which were $490 \mathrm{~m}$ apart (Fig. 1), was characterised by areas of fine sediments mixed with coral rubble at the base of the mounds that 
changed to coral rubble when approaching the crests. Dives 1 and 2 showed a rather similar taxonomic composition with only a change in the dominant taxa (Fig. 2).

Dive 1 was dominated by dense populations of M. oculata accompanied by L. pertusa (Fig. 3), which represents the main constructor building the mini-mound like features located at the crest of the coral mounds. The two species were observed closely cohabiting and even in some cases fusing colony branches (Fig. 4). P. rigida was the second most abundant species in this dive followed by other megafaunal species such as L. glaberrima, Pachastrella sp. and A. hirsuta. Megafauna in Dive 2 was dominated by P. rigida and Pachastrella sp., accompanied by other abundant taxa, like A. hirsuta, M. oculata and A. setubalense. Even though there was not a substantial difference in species richness between dives, Dive 2 presented the highest value for this parameter, with 28 taxa compared to the 25 from Dive 1. In regards to species diversity $\left(\mathrm{H}^{\prime}\right)$, both dives presented very similar values (Dive 1: $\mathrm{H}^{\prime}=3.0$ / Dive 2: $\mathrm{H}^{\prime}=3.1$ ), regardless of the dramatic decrease in living CWC abundance from Dive 1 to Dive 2 (from 967 colonies in Dive 1 to 178 in Dive 2) (Fig. 2).

\subsubsection{Southern sector - Dive 3}

In this dive, $15.1 \mathrm{~km}$ south of the northern dives (Fig. 1), video footage showed that the type of substratum along the mound's flanks was similar to the one observed in the northern region (coral rubble mixed with fine sediments) although with a higher abundance of fine sediments.
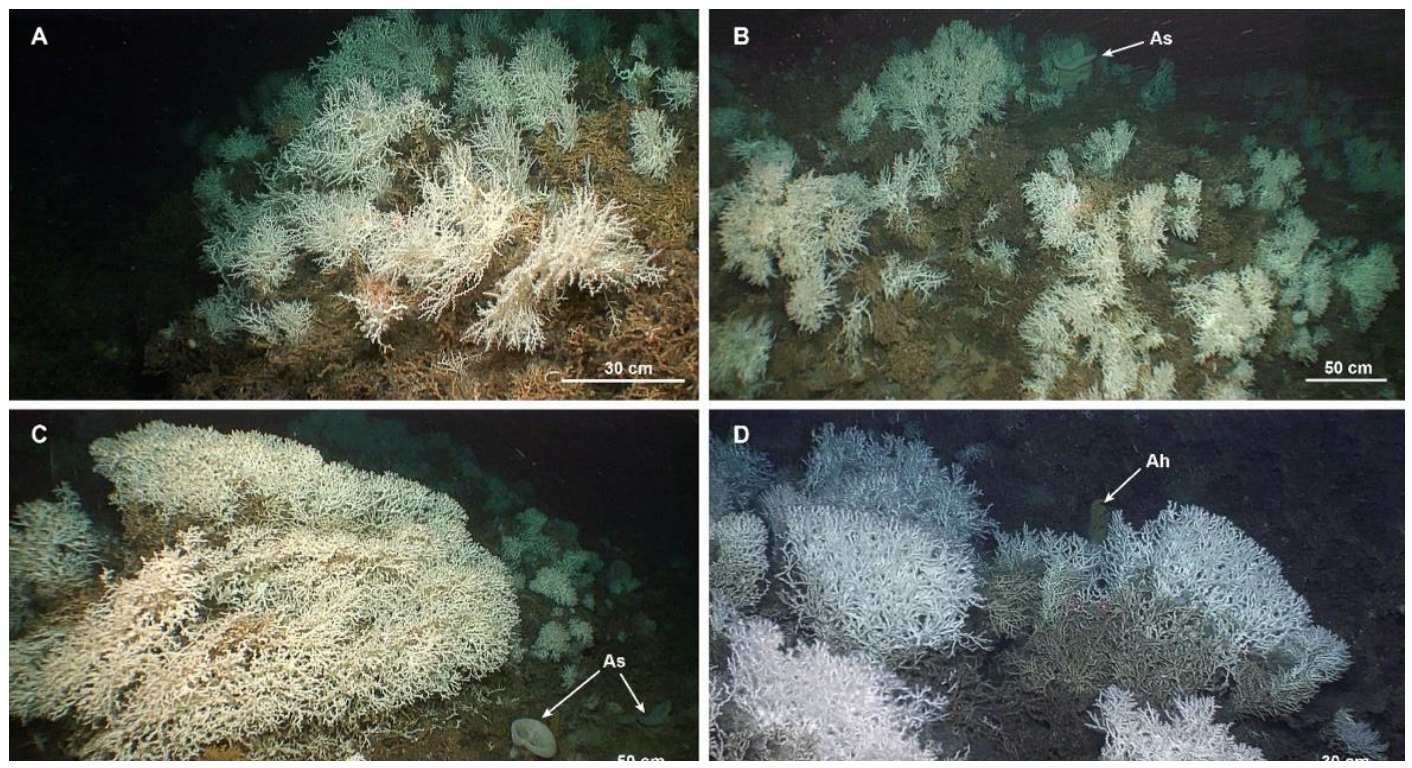

Figure 3. Living reefs of M. oculata (A, B) and L. pertusa (C, D) forming the mini-mounds observed on top of the northern Cabliers Province. The largest L. pertusa colony measured in the area is $306 \mathrm{~cm}$ wide (C). Arrows indicate some of the accompanying megabenthic species living within and around the reefs. Ah: A. hirsuta, As: A. setubalense 


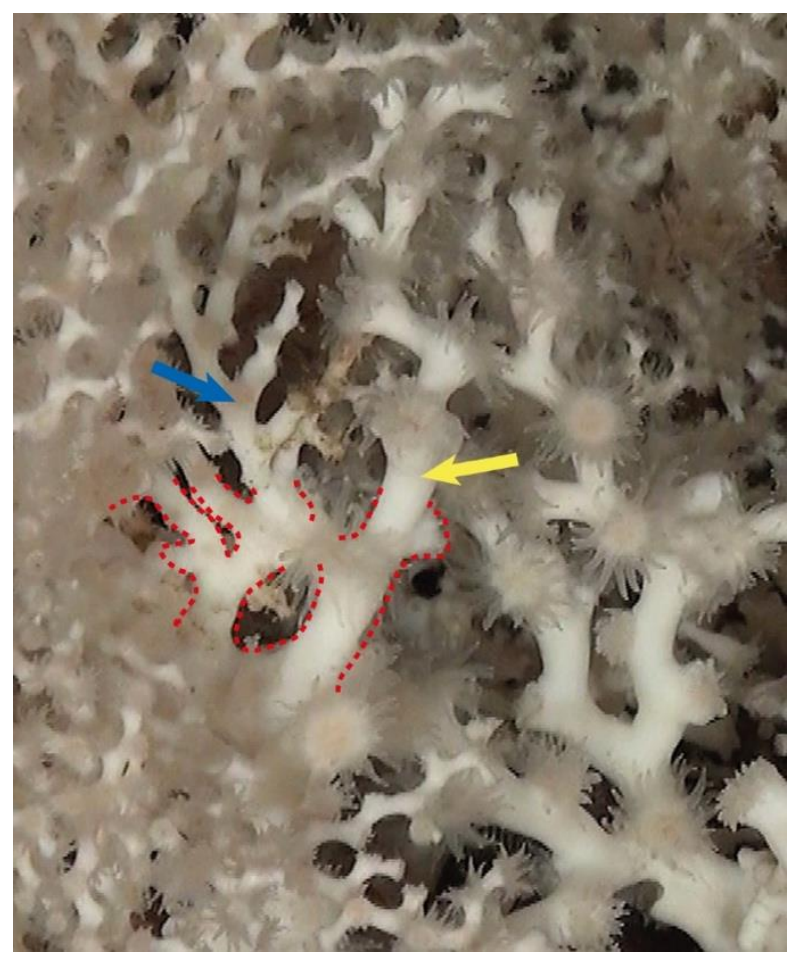

Figure 4. L. pertusa (yellow arrow) and M. oculata (blue arrow) chimaera-like colony. Silhouette of the fusing branches is highlighted by a red dashed line.

451 The same increase in deposited sediment was observed at the crest, where the dead coral 452 framework was draped by a larger amount of fine sediments than in northern Cabliers. Video 453 data collected during Dive 3 also showed a different combination of dominant species in 454 comparison to the northern sector (Fig. 2). This dive was essentially dominated by the 455 gorgonian species A. hirsuta (55\%) and characterised by very a few colonies of M. oculata.

456 Furthermore, squat lobsters and $P$. larix were also more abundant in this dive in comparison to 457 the northern ones, where they just occurred as accompanying species of M. oculata and $L$. 458 pertusa assemblages. Although the number of species observed in Dive 3 was the same as in 459 Dive 1, the diversity of the former was much lower (Dive $3 \mathrm{H}^{\prime}=2.027$ ), probably due to the 460 dominance of three species that represented over $80 \%$ of the observed organisms (Fig. 2).

\subsection{Scleractinian cold-water corals}

\subsubsection{Density and distribution}

465 M. oculata was the most abundant scleractinian species growing on Cabliers, representing 85\% 466 of the total (scleractinian) abundance in contrast with the $8 \%$ of L. pertusa and $6 \%$ of 467 Dendrophyllia cornigera. As shown in Figure 5 and Table 2, living CWC density in the 
northern sector of the province decreases from Dive 1 to Dive 2, with almost a total absence of these species occurring in Dive 3 (i.e. southernmost mound sector). The maximum density values for M. oculata and L. pertusa were 6 and $5 \mathrm{col} \cdot \mathrm{m}^{-2}$, both of them observed in Dive 1 (Fig. 5). White and orange chromatic morphotypes were found for both species, with the first being the most abundant (>95\%). M. oculata and L. pertusa showed greater densities at the crest of the mounds, especially towards the northernmost part of the province (290-320 m water depth) (Figs. 3, 5). Conversely, the mounds' flanks, which were mainly covered by coral rubble, were almost completely depleted of CWC (Fig. 5). This is particularly evident in Dive 1 , where there were no corals growing on the flanks or the densities were comparatively rather low (Fig. 5). Dive 2 and 3 presented lower densities of both coral species regardless of the location and thus, for these dives, density differences between mound's crest and flanks were less apparent. Furthermore, in Dive 1, coral density on the mound's crest was found to be significantly and positively correlated to the presence of mini-mounds ( $\mathrm{p}<0.001, \rho=0.4)$, identified by high BPI values (Fig. S2). This CWC distribution pattern was apparent in the detailed section of the Dive 1 density plot (Fig. 5B), in which the density peaks for both $M$. oculata and L. pertusa match with the summits of the mini-mound features observed on the crest of the mound.

Table 2. Average density of the most abundant and relevant species in each ROV dive performed on the Cabliers Coral Mounds, with scleractinian CWCs also displaying average colony size.

\begin{tabular}{|c|c|c|c|c|c|c|c|c|c|}
\hline & \multicolumn{2}{|c|}{$\begin{array}{c}\text { Madrepora } \\
\text { oculata }\end{array}$} & \multicolumn{2}{|l|}{$\begin{array}{l}\text { Lophelia } \\
\text { pertusa }\end{array}$} & $\begin{array}{c}\text { Acanthogorgia } \\
\text { hirsuta }\end{array}$ & $\begin{array}{c}\text { Parantipathes } \\
\text { larix }\end{array}$ & $\begin{array}{l}\text { Phanopathes } \\
\text { rigida }\end{array}$ & $\begin{array}{l}\text { Leiopathes } \\
\text { glaberrima }\end{array}$ & $\begin{array}{c}\text { Asconema } \\
\text { setubalense }\end{array}$ \\
\hline & Density $\left(\right.$ patch m ${ }^{-2}$ ) & Size $(\mathrm{cm})$ & Density $\left(\right.$ patch $\mathrm{m}^{-2}$ ) & Size $(\mathrm{cm})$ & \multicolumn{5}{|c|}{ Density $\left(\right.$ col. $\left.\mathrm{m}^{-2}\right)$} \\
\hline Dive 1 & $0.81 \pm 1.87$ & $21.6 \pm 11.5$ & $0.14 \pm 0.53$ & $49.3 \pm 38.3$ & $0.27 \pm 0.72$ & $0.08 \pm 0.3$ & $0.65 \pm 1.6$ & $0.29 \pm 0.98$ & $0.17 \pm 0.51$ \\
\hline Dive 2 & $0.28 \pm 0.7$ & $11.34 \pm 6.4$ & $0.04 \pm 0.25$ & $31.8 \pm 20.6$ & $0.36 \pm 0.82$ & $0.05 \pm 0.24$ & $1.14 \pm 1.89$ & $0.03 \pm 0.29$ & $0.27 \pm 0.37$ \\
\hline Dive 3 & $0.02 \pm 0.17$ & $9.25 \pm 2.6$ & $0.002 \pm 0.05$ & - & $1.31 \pm 2.25$ & $0.33 \pm 0.71$ & - & - & - \\
\hline
\end{tabular}

\subsubsection{Size structure}

490 In total, 1178 and 139 colonies of M. oculata and L. pertusa were measured, some of them being out of the video analysis range $(1 \mathrm{~m})$ for species density quantification. Similarly to the observed density pattern, the average size of these corals decreased from Dive 1 to Dive 2 (Table 2), with L. pertusa being almost absent in Dive 3, where only one colony was observed and measured. Colony size ranged from 4 to $130 \mathrm{~cm}$ for M. oculata and from 7 to $306 \mathrm{~cm}$ for L. pertusa (Fig. 3). The high abundance of M. oculata in Dive 1 allowed to observe that colonies found on the flanks of the mound had significantly smaller $(\mathrm{p}<0.001)$ average sizes $(12 \pm 4.6 \mathrm{~cm})$ than the ones at the crest $(22.1 \pm 8.9 \mathrm{~cm})$ (Fig. 6C). Considering the colonies from the whole study area, both $M$. oculata and L. pertusa had a higher percentage of smaller 
A
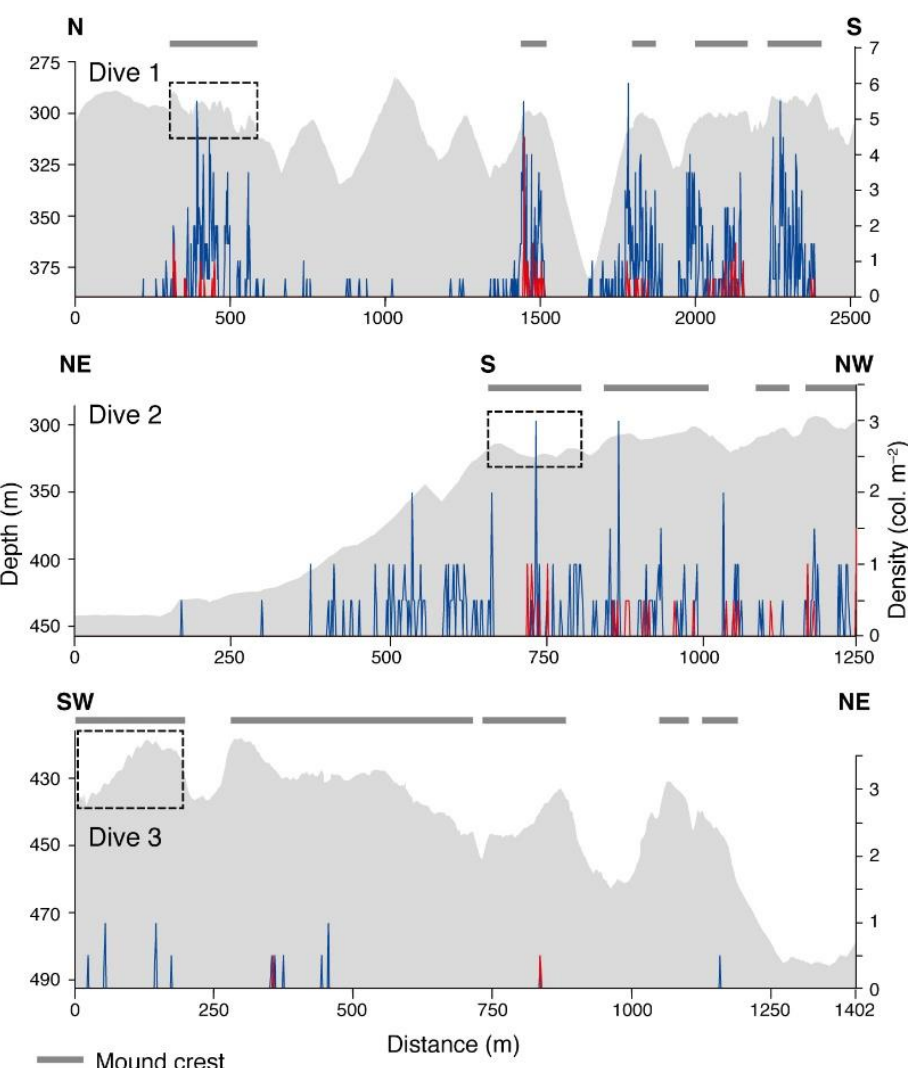
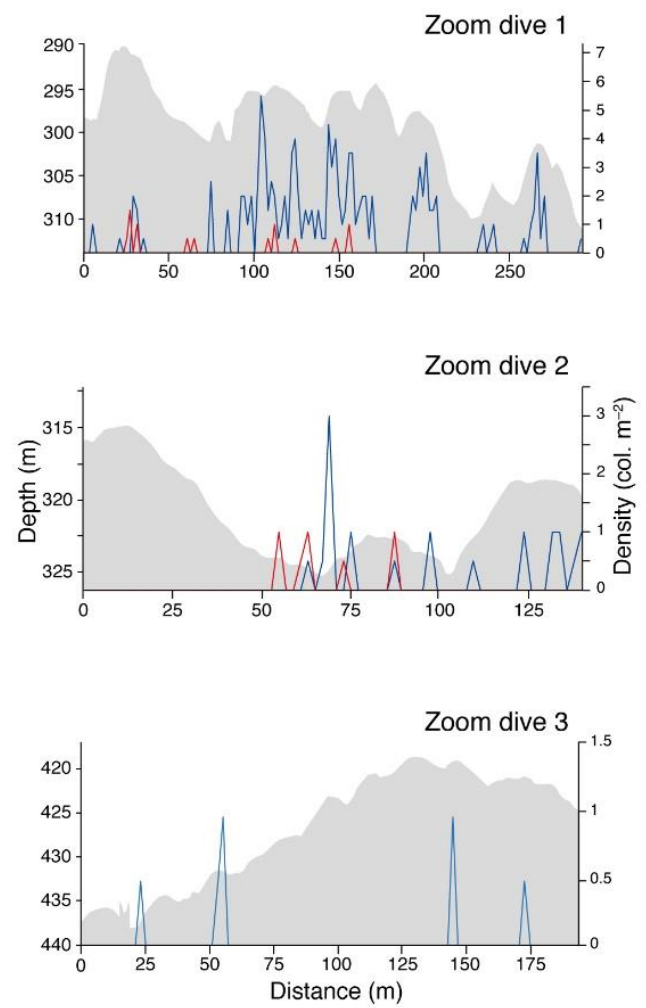

Figure 5. Bathymetric profile (grey shading) and density plots of Madrepora oculata (blue) and Lophelia pertusa (red) for each ROV dive (A). Zooms from the black-dotted boxes in graph A, which allow to appreciate the correlation between coral density and mini-mound summits (B). Dark grey lines on top of the graphs indicate the fragments of each dive where the ROV was travelling over the crest of the mounds. Transect orientation is noted at the top of each graph.

499

500

501

502

503

504

505

506

507

508

509

510

511

size classes than expected in a normal distribution, with significantly positive values of skewness $(\mathrm{p}<0.001$, skew⿳ $=2.42$ and skew $=3.79$ respectively $)$ and presented a long-tailed distribution $\left(\mathrm{p}<0.001\right.$, kurt $_{\mathrm{M}}=15.92$ and kurt $\left._{\mathrm{L}}=24.34\right)$ with some large colonies $($ Fig. 6).

\subsection{Main Associated Species}

Amongst the most abundant species observed on Cabliers, only the gorgonian A. hirsuta and the black coral $P$. larix occurred in all dives, with their density increasing towards the south of the mound province (Table 2, Fig. 7). The maximum density values of $A$. hirsuta and $P$. larix were 11.5 and $3 \mathrm{col} \cdot \mathrm{m}^{-2}$ respectively (Fig. 7). The distribution of A. hirsuta and P. larix was widespread across the mounds, although they both presented their highest abundances at the crest (Fig. 7). Both A. hirsuta and P. larix showed greater abundances in Dive 3 (southern Cabliers), where living framework-building CWCs were absent and these two species could 

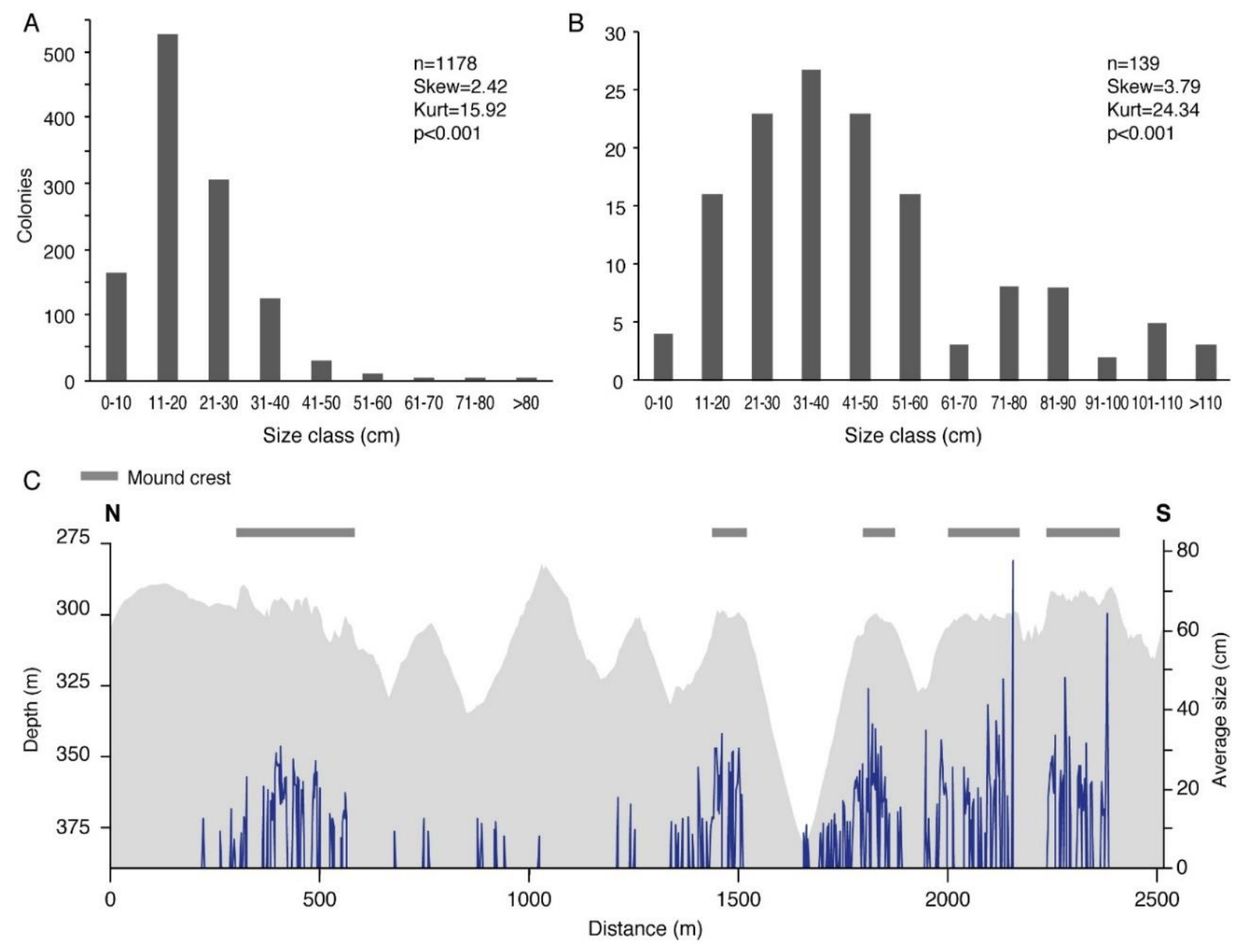

Figure 6. Colony size structure of Madrepora oculata (A) and Lophelia pertusa (B), together with the average size of M. oculata every $2 \mathrm{~m}^{2}$ along Dive 1 (C). Grey shading indicates the bathymetric profile of the dive. Dark grey lines denote the fragments of the dive where the ROV operated along the mound's crest. Transect orientation is noted at the top of graph C. n: number of colonies; Skew: skewness; Kurt: kurtosis.

512 thrive on the exposed dead coral framework that constitutes the mound's crest (Fig. 7, see also 513 Fig. 9).

514 The black corals $P$. rigida, L. glaberrima and the sponge A. setubalense were only found in 515 Dive 1 and 2, where living CWCs were abundant. Both P. rigida and A. setubalense presented 516 a higher average density in Dive 2. The highest density value observed for P. rigida and $A$. 517 setubalense was 7.5 living-patches $\cdot \mathrm{m}^{-2}$ and $6.5 \mathrm{col} \cdot \mathrm{m}^{-2}$ respectively (Fig. 7). L. glaberrima had 518 a maximum density of $5.5 \mathrm{col} \cdot \mathrm{m}^{-2}$ (Fig. 7). P. rigida and L. glaberrima showed a high density 519 on the coral rubble from the mound's flanks of Dive 1, for water depths ranging from $300 \mathrm{~m}$ to 520375 m (Fig. 7). However, in Dive 2 L. glaberrima was nearly absent and the flanks were 521 dominated by $P$. rigida. The latter species was also observed growing on the mounds' crest at 522 the end of Dive 1 and throughout the entire Dive 2. The sponge A. setubalense was observed 523 with a greater density on the mound's crest, with up to $2.5 \mathrm{ind} \cdot \mathrm{m}^{-2}$, using the coral framework 

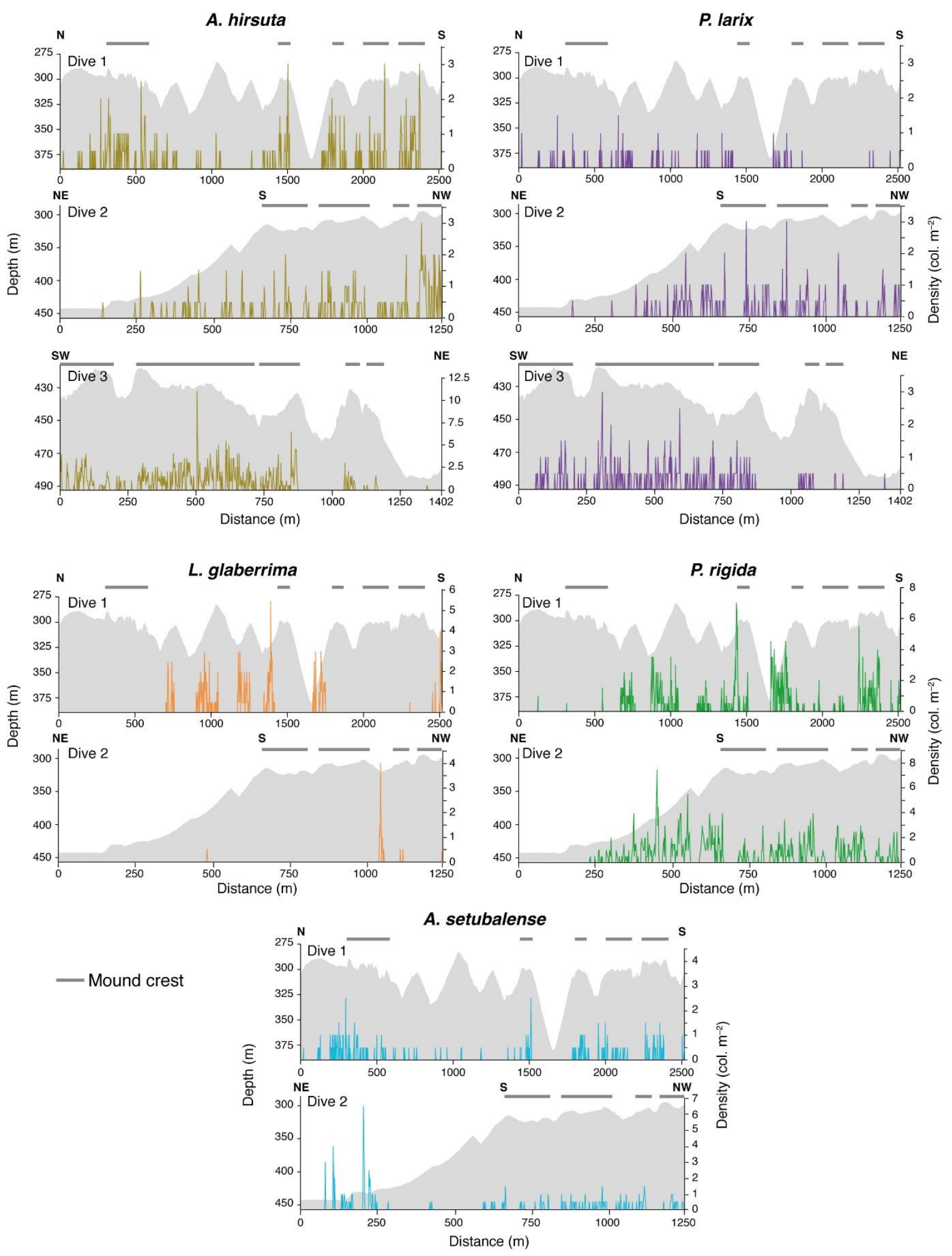

Figure 7. Bathymetric profile (grey shading) and density plots of Acanthogorgia hirsuta, Parantipathes larix, Leiopathes glaberrima, Phanopathes rigida and Asconema setubalense. Dark grey lines denote the fragments of the dive where the ROV operated along the mounds' crest. Transect orientation is noted at the top of each dive. 
as substratum to colonise. However, there was one exception at the beginning of Dive 2, where this species was observed growing on top of a volcanic outcrop at $\sim 425 \mathrm{~m}$ water depth, reaching its highest density $\left(6.5 \mathrm{ind} \cdot \mathrm{m}^{-2}\right)$.

Throughout the three ROV dives a total of 519 fish individuals were observed, from which 184 were identified in Dive 1, 195 in Dive 2 and 138 in Dive 3. The most abundant species was Helicolenus dactylopterus with 181 individuals, followed by Hoplostethus mediterraneus $(\mathrm{n}=$ $175)$ and Nezumia aequalis $(\mathrm{n}=60)$. Other species, some of them considered as commercially valuable, such as Pagellus bogaraveo, Conger conger, Scorpaena scrofa and some pleuronectids were also observed along Cabliers Coral Mounds. 111 individuals of $H$. dactylopterus were measured, showing sizes ranging from 5.1 to $35.6 \mathrm{~cm}$ and an average total length of $16.8 \pm 7.4 \mathrm{~cm}$. The $20 \%$ percent of these individuals have a length under $10 \mathrm{~cm}$, which corresponds to the size of recruit and juvenile stages.

\subsection{Environmental drivers and assemblages}

The set of CCA analyses performed adopting sampling units with different sizes $(2,4,10$ and $20 \mathrm{~m}^{2}$ ) showed an increase in the inertia explained by seafloor features with larger sampling units (Table S2). However, with increasing sampling unit size, CCA faunal and environmental resolution were reduced due to a decrease in the number of sampling units and a higher variability of environmental factors within each sampling unit. Therefore, the optimal sampling unit size for the CCA analysis was set at $10 \mathrm{~m}^{2}$, which had the best equilibrium between percentage of inertia explained by seafloor features and CCA resolution.

The ANOVA-like permutation analysis demonstrated that all environmental factors (depth, slope, aspect, substratum type and BPI), apart from terrain roughness, were statistically significant predictors $(\mathrm{p}<0.01)$ and together explained $19.7 \%$ of the variation in species abundance. The first two CCA axes represented 10.3 and 5.6\% of the total variance. Regarding predictor performance, the combined explanatory power of the four substratum types was the most relevant in determining species distribution, explaining $9.9 \%$ of the variation, followed by depth, which explained a further $7.4 \%$ (Fig. 8). The CCA ordination together with the ANOVA-like permutation tests, allowed identifying four megabenthic assemblages characterised by different dominant species and controlled by different seafloor features (Fig. 8).

Assemblage 1 was mainly characterised by the scleractinians M. oculata and L. pertusa together with the echinoderm Cidaris cidaris and the sponge A. setubalense (Fig. 3). These 
species mainly occurred on the northern and shallower parts of the mounds' crests (Dive 1,2), growing on dead coral framework (CF) (Fig. 8).

561 Assemblage 2 occurred on the deeper and southern parts of the mounds' crests (Dive 3), where dead coral framework with fine sediments (CFFS) was the main substratum type. These areas
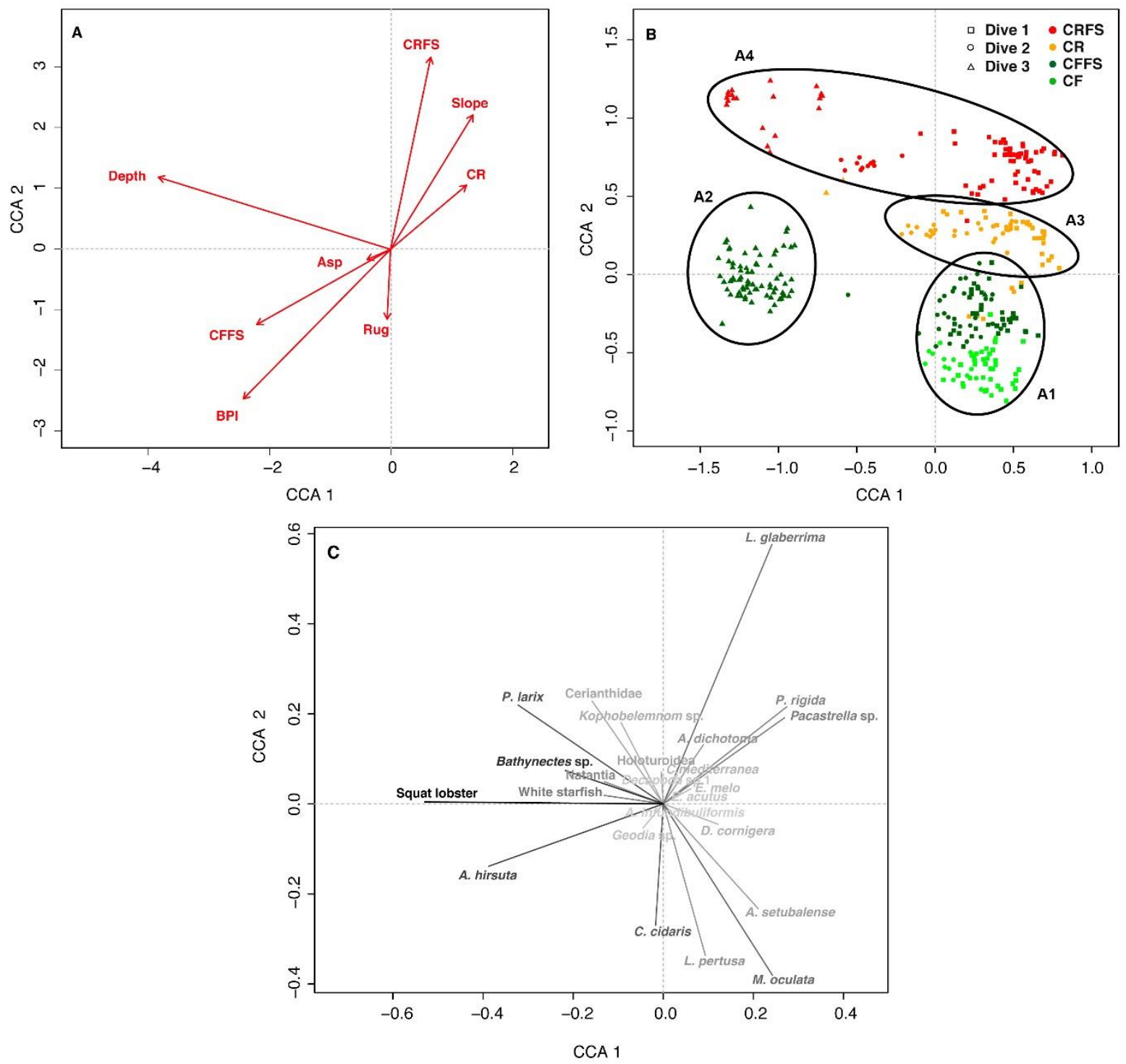

Figure 8. Canonical correspondence analysis (CCA) results. The first bi-plot (A) shows all significant seafloor variables considered in the analysis in relation to the axes CCA1 and CCA2. The second bi-plot (B) displays the $10 \mathrm{~m}^{2}$ sampling units ordination based on species abundance and composition, constrained by the seafloor variables and coloured according to their substratum type. The third bi-plot (C) shows the contribution of each species to the megabenthic assemblages. The grey scale of each species indicates the degree of correlation to the seafloor variables, being black the highest correlation. The length and position of the vectors gives information about their relationship to the axes. Vectors parallel to an axis denote a correlation and their length defines the strength of such correlation. CRFS: coral rubble and fine sediments, CR: coral rubble, CFFS: dead coral framework and fine sediments 
were covered by aggregations of the gorgonian $A$. hirsuta, squat lobsters and the anthipatharian P. larix (Fig. 8).

Assemblage 3 occurred on the northern and shallowest parts of the mounds' flanks (Dive 1,2), where the seafloor is steep and coral rubble (CR) is the most common substratum type. This assemblage is characterised by the presence of $P$. rigida, together with the incrusting sponge Pachastrella sp (Fig. 8).

Finally, Assemblage 4 comprehended sampling units from all ROV dives and presented a varying taxonomic composition. It was mainly characterised by the presence of L. glaberrima and other antozoans such as the pennatulacean Kophobelemnom sp., cerianthids and some colonies of $P$. larix. These taxa generally occurred on coral rubble with fine sediments (CRFS) on the deeper parts of the flanks of the mounds (i.e. steep slopes) (Fig. 8).

\section{DISCUSSION}

\subsection{Cabliers Coral Mound}

The Cabliers Coral Mounds are among the most extensive coral mound features in the Alboran Sea (Comas and Pinheiro, 2010; Fink et al., 2013; Lo Iacono et al., 2014; Lo Iacono et al., 2018b). As other mounds (Hovland and Risk, 2003; Buhl-Mortensen et al., 2010), they developed on a volcanic basement that can be observed at the start of Dive 2 and is well recognisable in the high-resolution AUV bathymetry. This outcrop probably functioned as a substratum for CWC colonization and subsequent mound development. As described in Duggen et al. (2004) the outcrop on which the Cabliers Coral Mounds developed, known as Cabliers Bank, probably consists of an andesite basement, dated Middle to Late Miocene.

As with some other giant coral mounds (Buhl-Mortensen et al., 2017), Cabliers ridge-like mounds could be the product of smaller mounds coalescing to form giant elongated coral mounds. This is suggested by the occurrence of numerous mini-mounds aligned along the crest of the northern Cabliers Mounds, where the most thriving CWC assemblages were observed. However, an extensive and more detailed geomorphological study of Cabliers Mounds is required to prove this hypothesis.

\subsection{Scleractinian cold-water corals}


The incidence of higher density of living CWC at the crest of the mounds agrees with previous observations from other coral mounds and is probably caused by the presence of more favourable environmental conditions (Freiwald et al., 2004; Huvenne et al., 2005; Davies et al., 2009; Lo Iacono et al., 2018). Furthermore, the dive segments that crossed the crest of the mounds, showed that the peaks in M. oculata and L. pertusa density generally matched with the presence of the mini-mound like features (Figs. 3, 5). Considering that the highest CWC density values are observed at the top of these mini-mounds, it could be hypothesised that these features are the engine that drives CWC mound growth (Lo Iacono et al., 2018b). These minimound features are comparatively elevated to the rest of the mound's crest, thus their summit is probably exposed to higher current speeds, which might prevent sedimentation on the corals growing there. Additionally, such current speeds might cause a higher amount of food to be advected towards the mini-mounds' summit, providing the most suitable conditions for CWC growth.

Framework-building CWC densities are highly variable in the Mediterranean Sea. The Cap de Creus Canyon, in the NW Mediterranean, presents average densities of both species oscillating between 0.1-0.4 col $\cdot \mathrm{m}^{-2}$ for M. oculata and $0.004-0.01 \mathrm{col} \cdot \mathrm{m}^{-2}$ for L. pertusa (Orejas et al., 2009; Gori et al., 2013). In the Lacaze-Duthiers Canyon, Gori et al. (2013) explored with an ROV a distance of $8362 \mathrm{~m}$, where 555 and 97 colonies of M. oculata and L. pertusa were counted. This would relate to an average density of $0.044 \mathrm{col} \cdot \mathrm{m}^{-2}$ and $0.012 \mathrm{col} \cdot \mathrm{m}^{-2}$ for each species, comparable to the values observed in other regions of the Mediterranean, where $M$. oculata and especially L. pertusa generally occur as small populations or sparse colonies on complex geomorphic features (Savini and Corselli, 2010; Lastras et al., 2016; Fabri et al., 2017; Taviani et al., 2017). Therefore, average densities of M. oculata and L. pertusa on northern Cabliers ( 0.81 and $0.14 \mathrm{col} \cdot \mathrm{m}^{-2}$ respectively) are considerably greater than the ones observed for most of the other CWC assemblages described in the Mediterranean Sea. Only the coraltopped mounds from Santa Maria di Leuca province seem to present an abundance comparable to the Cabliers assemblages, however no quantitative data are yet available for this area (Savini and Corselli, 2010; Vertino et al 2010; Savini et al., 2016; Bargain et al., 2017). In terms of coral mounds, almost the totality of these geomorphologic features discovered to date in the Mediterranean Sea are in a complete stage of decline, with only some sparse living colonies of M. oculata and L. pertusa (Hebbeln and Wienberg, 2016). The absence of anthropogenic footprint in the ROV footage suggests that the Cabliers living reefs are in a likely pristine status, which is remarkable considering its proximity to both the coasts of Spain and Morocco, where industrial fishing practices are intense (Aguilar et al., 2017). 
The northern mounds of the Cabliers Coral Mound Province resemble the characteristics of their thriving Atlantic counterparts, on which a mixture of abundant living coral and exposed dead coral framework is commonly observed (Buhl-Mortensen et al., 2010). The megabenthic assemblages observed in Dive 1 matches with the typical spatial patterns of living CWC reefs, in which the area occupied by dead coral framework is greater than the coverage of living corals (Mortensen et al., 1995; Buhl-Mortensen et al., 2017). The average density of M. oculata in northern Cabliers (Dive 1: $0.81 \mathrm{col} \cdot \mathrm{m}^{-2}$ ) presents similar values to those observed in the prolific Atlantic regions such as the Logachev Mounds (1.04 col $\cdot \mathrm{m}^{-2}$ ) (Arnaud-Haond et al., 2017). In contrast, L. pertusa density is much higher in the Logachev Mounds $\left(1.41 \mathrm{col} \cdot \mathrm{m}^{-2}\right)$ in comparison to Cabliers $\left(0.14 \mathrm{col} \cdot \mathrm{m}^{-2}\right)$. This makes sense, since Atlantic coral mounds generally present a higher relative abundance of $L$. pertusa contributing to form CWC reefs (Buhl-Mortensen et al., 2017). The reason for this discrepancy could be due to the higher water temperatures of the Mediterranean Sea compared to the north Atlantic. Warmer temperatures in the Mediterranean, which cause a higher oxygen demand by the corals (Dodds et al., 2007), are combined with a lower availability of dissolved oxygen (i.e. from 6-6.2 $\mathrm{ml} \mathrm{1}^{-1}$ in the North Atlantic to $3.75 \mathrm{ml} \mathrm{l}^{-1}$ in the Mediterranean) (Davies et al., 2008; Freiwald et al., 2009). In this setting, L. pertusa might be closer to its ecological boundary, which could explain its lower abundances compared to M. oculata (Dodds et al., 2007; Freiwald et al., 2009; Davies and Guinotte, 2011). However, this assumption would require further investigation.

Besides the high coral density observed on the northern region of Cabliers, $2 \%$ of M. oculata and $32 \%$ of $L$. pertusa coral colonies from these mounds reached sizes over $50 \mathrm{~cm}$ in diameter (Figs. 3, 6). This suggests that CWC have been thriving on northern Cabliers during the recent past. On the other hand, there is also an important percentage $(58 \%)$ of small colonies $(<20$ $\mathrm{cm}$ ) of M. oculata, which suggests either a high recruitment rate or frequent fragmentation of larger colonies into smaller ones. According to the skewness results, the L. pertusa population on Cabliers is characterised by medium-sized colonies $(20-40 \mathrm{~cm}=36 \%$ ) (Fig. 6). This trend could be a consequence of a lower recruitment rate and/or a lower fragmentation of L. pertusa, due to its thicker and less fragile skeleton in comparison to M. oculata. Gori et al. (2013) observed a similar trend in the Gulf of Lions, where L. pertusa also presented larger colony sizes than M. oculata. However, in that region, both species generally showed smaller coral colony sizes than the ones observed on Cabliers.

Along with CWC density, colony size also increased towards the crest of the Cabliers Coral Mounds. This is probably caused by a higher substratum stability that allows corals on the subhorizontal crest to grow larger than the ones on the sloping flanks. Simultaneously a greater 
food supply might occur across the crest of the mounds, where bottom currents are generally expected to be stronger (Mienis et al., 2012; Cyr et al., 2016; Lo Iacono et al., 2018). Similarly to what has been reported in other studies (Mastrototaro et al., 2010; Mienis et al., 2012; Duineveld et al., 2012; Oguz et al., 2014), the presence of flourishing CWC assemblages on Cabliers is probably linked to suitable oceanographic conditions. In this regard, the Cabliers Coral Mounds are located within the Levantine Intermediate Water, a water mass regarded by Taviani et al. (2017) as hosting most of the living CWC assemblages occurring in the Mediterranean Sea. Nevertheless, the CWCs present in Cabliers showed a dramatic decrease in abundance towards the southern region of the province (Figs. 2, 5). This pattern could be caused by the presence of slower current speeds in the southern region, which could explain the greater amount of fine sediments observed at the mound's crest. Weaker currents would also bring less amount of food to the corals and generate lower resuspension of organic material from the seafloor, preventing corals from a sufficient food intake (Duineveld et al., 2004). Furthermore, the crest of the coral mounds from southern Cabliers is found at a greater water depth (Dive 3: 420-445 $\mathrm{m}$ ) than the crest of the northern ones (Dive 1 and 2: 280-325 $\mathrm{m}$ ). This fits the results from the CCA analysis, where depth was found to be one of the main environmental drivers affecting species distribution (Fig. 8). In this sense, the southern, less prolific part of Cabliers would be considerably further away from the AW-LIW interface (150$200 \mathrm{~m}$ water depth) (Millot, 2009). The global coral mound distribution generally matches with the presence of close sharp thermo- and haloclines, indicating that such water mass interfaces might be relevant for the proliferation of CWC reefs (Dullo et al., 2008; Matos et al., 2017; Lo Iacono et al. 2018). However, the considerable differences in CWC abundance within the northern sector of Cabliers (Dive 1 and Dive 2), suggests that at a local-scale, other variables than depth contribute towards the creation of suitable conditions for the development of such thriving CWC assemblages.

\subsection{Megabenthic species distribution and environmental variables}

The CCA analysis divided the Cabliers fauna into four main assemblages, which were mainly determined by substratum type and water depth, two environmental variables that have been long regarded as important factors determining species distribution in benthic habitats (Zajac et al., 2000; Santín et al., 2017, 2019). The most common substratum types on a coral mound derive from dead CWCs, which suggests that as some other ecosystem engineers, framework- 
building corals affect the distribution of the rest of species in the habitat even after they die (Jones et al., 1994).

The megabenthic fauna observed on the Cabliers Coral Mounds mostly features sessile benthic suspension feeders (e.g. octocorals, antipatharians, sponges) that generally grow on the hard substrata provided by dead coral framework and off-mound outcropping volcanic rocks. This is the typical type of fauna found worldwide on coral mounds (Roberts et al., 2006; Mastrototaro et al., 2010; Buhl-Mortensen et al., 2010, 2017). Such geomorphological features are indeed areas with a high hard substrata availability for larval settlement and generally exposed to strong bottom currents, which provide a suitable environment for suspension feeding (Mortensen and Fosså, 2006; Mienis et al., 2012).

Most of the species associated with stony CWCs in Cabliers are also conspicuous in other areas of the Mediterranean Sea. For instance, A. hirsuta has also been observed in other regions of the Alboran Sea (i.e. Al Idrissi Bank and Chella Mound) (Coiras et al., 2011; De la Torriente et al., 2018), as well as on shelf edge and slope settings of the western and central Mediterranean Sea (Bo et al., 2015; Cau et al., 2015; Oceana, 2015; Grinyó et al., 2016). Within the antipatharians, L. glaberrima is a very abundant species in areas of the upper slope of the Mediterranean Sea (>130 m water depth) (Vertino et al., 2010; Angeletti et al., 2014; Bo et al., 2015; Ingrassia et al., 2016). The same is true for P. larix, which is widespread across the Mediterranean, mostly growing on the upper continental slope (Bo et al., 2014a). On the contrary, the high abundance of $P$. rigida is remarkable, considering this species is Atlantic (Opresko, 2009) and has been observed for the first time in the Mediterranean Sea on the Cabliers Coral Mounds (Bo et al., 2018). The fishes found on Cabliers have also been observed in other bathyal regions of the Mediterranean Sea (Fabri et al., 2014; Taviani et al., 2017; Deval et al., 2018). Furthermore, H. dactylopterus presented individuals covering all the size classes previously described for this species (Deval et al., 2018), which means that these fishes inhabit CWC reefs during most of their life stages. It is especially important to point out the $20 \%$ of juveniles and recruits $(<10 \mathrm{~cm})$ of this species observed on the Cabliers Coral Mounds, which confirms the use of CWC assemblages as nursery grounds by a commercially valuable species. In terms of spatial distribution, some of the sessile species mentioned have been observed to occur on the mini-mounds located at the crest of Cabliers Coral Mounds. However, when dense aggregations of living CWC cover the summit of these mini-mounds, the associated species are displaced to areas with a higher percentage of exposed dead coral framework (Fig. 9). The availability of this substratum increases towards the mini-mound flanks and there, organisms such as $A$. setubalense and P. larix increase in abundance (Fig. 9). Nevertheless, smaller 


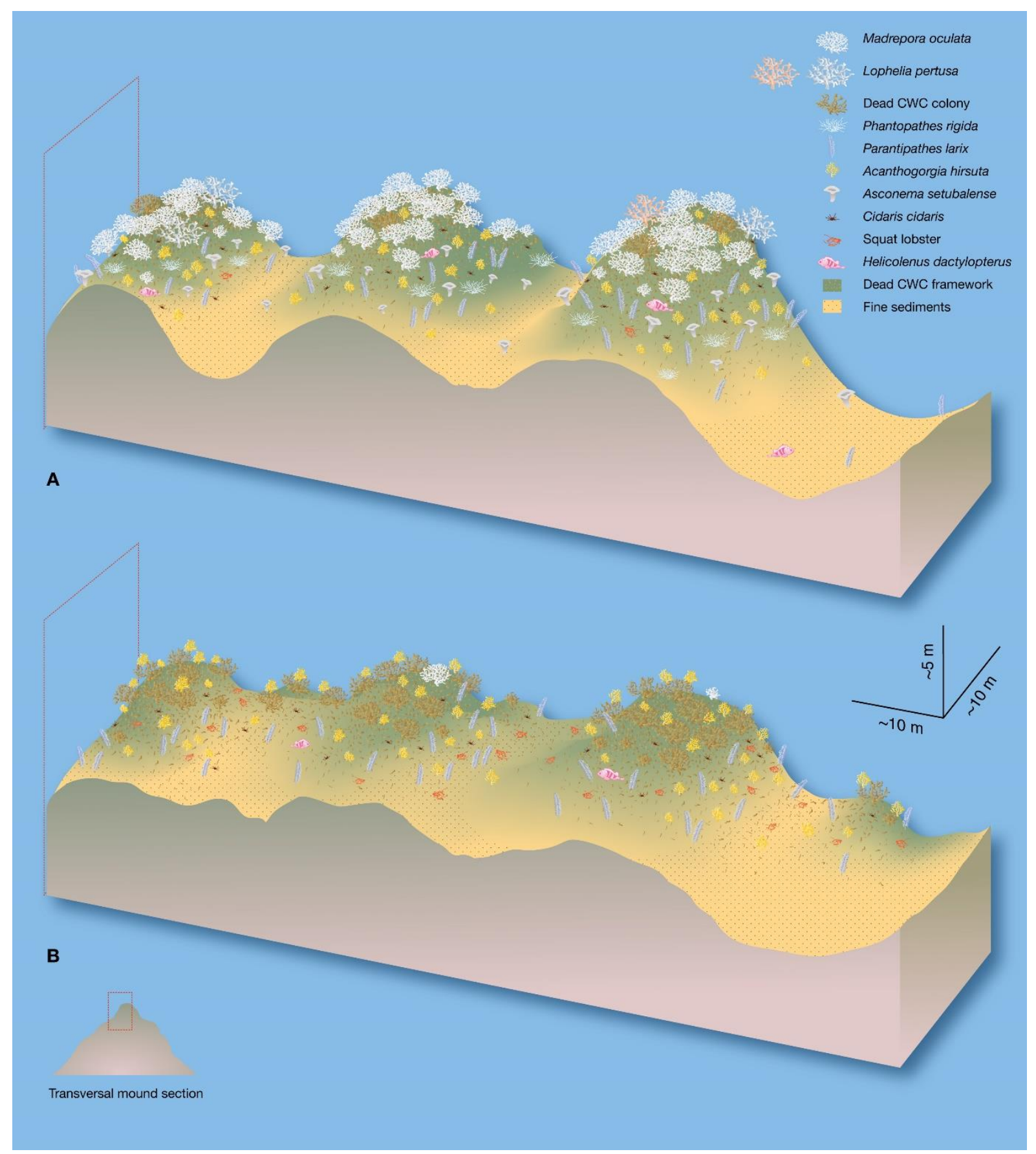

Figure 9. Schematic representation of the megabenthic species distribution on the mini-mounds located on the crest of northern (A) and southern (B) Cabliers Coral Mound. species, such as $A$. hirsuta and $C$. cidaris, manage to grow amongst dense $M$. oculata and $L$. pertusa colonies (Figs. 7, 9). The regions between mini-mounds, where fine sediments drape the dead coral framework or are interspersed with it, seem to have a lower megabenthic abundance (Fig. 9). This is probably due to the lack of hard substratum on which benthic sessile organisms could settle.

737 Although all the mentioned species were observed in northern Cabliers, they do not present a 738 homogeneous distribution along the mounds. Similarly to framework-building CWC, some 
species such as $P$. rigida, A. setubalense and L. glaberrima decrease in abundance or are completely absent at the southern region of Cabliers (Dive 3; Fig. 2, 9). This suggests that a marked change in the environmental conditions (e.g. greater depth, weaker current regime or lower food supply) occurs towards the southern part of the mound, which far from only affecting scleractinian corals is also detrimental for the proliferation of the latter taxa.

Some other species, such as $A$. hirsuta and $P$. larix show an increase in abundance towards south Cabliers. This pattern could be related to the absence of living CWCs in that region, which allows other organisms to thrive and dominate the areas of dead coral framework and fine sediments (Fig. 7, 9). We hypothesise that when environmental conditions are suitable, framework-building corals outcompete these species, which are therefore confined to less suitable sectors of the reef, where dead CWC framework dominates as substratum.

In conclusion, Cabliers megabenthic assemblages change from thriving CWC reefs at the north (Dive 1), to dead coral framework mixed with fine sediments and colonised by octocorals, antipatharians and squat lobsters, at the south (Dive 3) (Fig. 2, 9). The changes in taxonomic composition, abundance and diversity from north to south Cabliers could be a representation of the different ecological succession stages that can occur in a coral mound throughout flourishing and decline periods (Mortensen and Fosså, 2006). However, in order to get a more comprehensive overview of Cabliers and confirm these observations, more images or videotransects should be acquired along and across the mounds, and a more detailed study of the environmental conditions should be performed.

\subsection{Faunal comparison with Mediterranean and Atlantic Mounds}

The characterisation of biogeographic provinces has essential implications for understanding the evolutionary and ecological processes that caused the existing large-scale biodiversity patterns (Whittaker et al., 2005; Lomolino et al., 2006). In this sense, they can be of use to predict the areas where certain habitats or species can occur and to foresee the response of such ecosystems to cumulative disturbances (Rice et al., 2010). Biogeographic provinces might also help to detect potentially vulnerable marine ecosystems (VMEs) and to create representative marine protected area networks (Rice et al., 2010). Therefore, comparing the taxonomic composition of the Cabliers Coral Mound megafauna with the one observed on analogous Mediterranean and Atlantic geomorphologic features might help towards a better understanding of the taxonomic linkages amongst the known CWC mound provinces, which 
would improve the baseline needed for the designation of sensible marine protected area networks.

The type of megafaunal taxa observed on Cabliers showed several similarities with what has been previously described on the thriving Atlantic CWC mounds (Mortensen and Fossa, 2006; Henry and Roberts, 2007; Buhl-Mortensen et al., 2017). Some organisms such as gorgonians, hexactinellid sponges, demosponges, squat lobsters, and sebastid fishes are within the shared fauna between Cabliers Coral Mounds and its Mediterranean and Atlantic analogues (Roberts et al., 2008, 2009a; Vertino et al., 2010; Purser et al., 2013; Ross et al., 2017). However, as observed in Buhl-Mortensen et al. (2017), the fauna associated to CWC mounds can present considerable taxonomic differences amongst provinces, even though such species belong to the same functional groups.

Within the Mediterranean Basin, the coral mound clusters are in a general stage of decline. Some of them have been reported to be mostly covered by aggregations of gorgonians, sponges and echinoderms (Hebbeln, 2009; Hebbeln and Wienberg, 2016). Probably the coral reefs observed in Santa Maria di Leuca (Central Mediterranean Sea) are the closest ones to Cabliers in terms of reef-building coral abundance and megafaunal composition. Both of them present demosponges, antipatharians and gorgonians as the main species accompanying $M$. oculata and L. pertusa reefs (Mastrototaro et al., 2010; Vertino et al., 2010). Within these taxonomic groups, Pachastrella sp., A. hirsuta and L. glaberrima dominate the accompanying fauna in both regions (Mastrototaro et al., 2010; Vertino et al., 2010). However, the hexactinellid sponge A. setubalense and the antipatharian $P$. rigida are only observed in abundance on Cabliers.

Norwegian CWC mounds exhibit gorgonians, demosponges and anemones, within the most conspicuous reef associated fauna. The bivalve Acesta excavata is also a common species on these mounds. Although both Norwegian coral mounds and Cabliers contain gorgonians, the former are populated by Paragorgia arborea and Primnoa resedaeformis (Purser et al., 2013; Buhl-Mortensen et al., 2017), while the latter is covered by dense aggregations of A. hirsuta. The same occurs with demosponges, which are an important component of Cabliers (i.e. Pachastrella sp.), yet the dominant species are different from those observed on Norwegian mounds (i.e. Geodia sp. and Mycale lingua) (Purser et al., 2013; De Clippele et al., 2018). Furthermore, bivalves and anemones are not within the dominant associated fauna observed on Cabliers.

The Mingulay Reef Complex, located on the Scottish continental shelf, presents a taxonomic composition similar to the Norwegian mounds, with no hexactinellid sponges and the demosponges Geodia sp. and M. lingua occurring among the L. pertusa colonies (Roberts et 
al., 2009a; De Clippele et al., 2018). However, dense gorgonian aggregations were not observed on the Mingulay Reef Complex (Roberts et al., 2009a).

Irish and African Atlantic CWC mounds are generally populated by large assemblages of hexactinellid sponges, whose silicic skeleton contributes to the structural formation of the mounds (van Soest et al., 2007; Henry and Roberts, 2007; Buhl-Mortensen et al., 2017). Although this taxonomic group is also present on Mediterranean coral mounds (i.e. Cabliers), the species do not coincide. Rosella nodastrella, Aphrocallistes bocagei and A. beatrix dominate the associated fauna of Irish and African coral mounds (van Soest et al., 2007; Henry and Roberts, 2007; Buhl-Mortensen et al., 2017), whereas A. setubalense is the dominant hexcatinellid sponge on Cabliers. Such as in Norwegian Mounds, anemones (i.e. Phelliactis sp.), and bivalves (i.e. Acesta sp.) thrive on the Irish and the African mounds respectively (Roberts et al., 2008; Buhl-Mortensen et al., 2017).

On the western Atlantic, in the Gulf of Mexico and off North Carolina and Florida's coast, several coral mounds arise (Ross, 2006; Ross and Nizinski, 2007; Hebbeln et al., 2014; Mienis et al., 2014; Ross et al., 2017). In accordance to the African mounds, the hexactinellid sponge A. Beatrix is observed forming aggregations on these American mounds (Ross and Nizinski, 2007). Other suspension feeders such as gorgonians (Keratoisis spp.), antipatharians ( $L$. glaberrima and Bathypathes alternata) and stylasterid corals are also amongst the main associated species to the L. pertusa reefs of these mounds.

As already stated, Atlantic coral mounds mostly present L. pertusa as the main reef-building species, sometimes accompanied by M. oculata, Enallopsamia profunda and Solenosmillia variabilis (Roberts et al., 2008; Buhl-Mortensen et al., 2017; Ross et al., 2017). On the other hand, Cabliers shows a considerably higher proportion of $M$. oculata, accompanied by $L$. pertusa and D. cornigera.

This faunistic comparison among coral mound provinces suggests that although most taxonomical groups of organisms observed on Cabliers are common to those witnessed on Atlantic coral mounds (Henry and Roberts, 2007; Ross and Nizinski, 2007; Purser et al., 2013; Buhl-Mortensen et al., 2017; Ross et al., 2017), there are considerable differences at the species level. These variations in the megafaunal composition are probably determined by biogeographic factors. Although in most regions the species associated to CWC mounds are probably subjected to similar conditions in terms of current speed and food supply, other environmental variables, such as water temperature and dissolved oxygen might influence their distribution. Another factor that limits species distribution is larval dispersal, which depends on water mass circulation, larval longevity and motility. Therefore, changes in environmental 
variables due to the incidence of contrasting oceanographic conditions, together with the presence of biogeographical barriers (e.g. Strait of Gibraltar) might prevent some of these species from being found in different CWC mound provinces.

Even though CWCs were already known to host a large diversity of organisms, the taxonomic differences observed between mound provinces suggest that the number of species associated to these habitats is even higher than previously thought (Roberts et al., 2006). As a consequence of the high biodiversity of these ecosystems and their high vulnerability to anthropogenic disturbances (Althaus et al., 2009; Armstrong et al., 2014), many measures have been taken by the United Nations and the Food and Agriculture Organisation (FAO) to protect CWC habitats (Davies et al., 2017). Several international legislations have defined CWC assemblages as vulnerable marine ecosystems (VMEs) and have included them in the list of endangered habitats (EU Habitats Directive, OSPAR, 2008). However, in order to efficiently implement such conservation measures, more detailed information about the distribution, taxonomic composition and ecological state of CWC mounds needs to be provided. This is especially true for the Mediterranean Sea, where to the moment, the Cabliers Coral Mounds are the only giant CWC mounds hosting living CWC reefs. Therefore, further exploring and research efforts are required in this field to unveil and study new coral mound provinces in order to better constrain the environmental conditions that allow the formation and endurance of these geomorphologically complex bioconstructions.

\section{CONCLUSIONS}

- ROV footage integrated with high-resolution AUV bathymetry unveiled thriving CWC reefs with uncommonly high coral densities occurring on the top of some of the Cabliers Coral Mounds, western Mediterranean Sea.

- Similarly to the Atlantic CWC mounds, coral density and size increase towards the top of the Cabliers Coral Mounds, probably due to higher food supply and structural stability.

- Statistical analyses showed the presence of four megabenthic assemblages, whose distribution was mainly determined by substratum type and depth.

- The presence of several $H$. dactylopterus individuals under $10 \mathrm{~cm}$ confirms that CWC assemblages are used by commercially valuable species as nursery grounds.

- The changes in CWC abundance, taxonomic composition and diversity between north and south Cabliers could be a representation of the different succession stages that can occur in a coral mound throughout flourishing and decline stages. 
- The taxonomic differences observed between Atlantic and Mediterranean coral mounds, in terms of megabenthic assemblages, indicate that the amount of species associated to CWC reefs is probably higher than previously thought.

- The present study helped to gain insight into the structure of Mediterranean CWC reefs and their associated species. However, a broader quantitative baseline would be required to better understand the environmental constraints of these ecosystems in the Mediterranean Sea and to contribute towards an improved management of CWC assemblages.

\section{ACKNOWLEDGEMENTS}

Guillem Corbera is funded by the Graduate School of the National Oceanography Centre Southampton (GSNOCS), with the collaboration of the NGO OCEANA. The data for this study was collected during the Spanish national project SHAKE (CGL2011-30005-C02-02, PI: Eulàlia Gràcia). We acknowledge the European Ocean facilities Exchange Group (OPEG) who facilitated the use of the AUV IdefX from IFREMER (France) and the EU Eurofleets-2 Project, which provided the ROV Max Rover from HCMR (Greece) during the SHAKE Cruise. We are indebted with the technical teams of UTM-CSIC, IFREMER and HCMR, for their support provided during the SHAKE cruise. We gratefully acknowledge all the participants on the SHAKE cruise and the crew on board of the R/V Sarmiento de Gamboa for their professional work during the expedition. Finally, we would like to thank the scientific illustrator Jordi Corbera for the design of the schematic representation of the assemblages found on Cabliers.

\section{REFERENCES}

Aguilar, R., Marín, P., Gerovasileiou, V., Bakran-Petricioli, T., Ballesteros, E., Bazairi, H., Bianchi, C.N., Bussotti, S., Canese, S., Chevaldonné, P., Evans, D., Fourt, M., Grinyó, J., Harmelin, J.-G., Jeudy de Grissac, A., Mačić, V., Orejas, C., Otero, M. d. M., Pergent, G., Petricioli, D., Ramos-Esplá, A.A., Rosso, A., Sanfilippo, R., Taviani, M., Tunesi, L., Würtz, M. (2017). Draft Guidelines for Inventoring and Monitoring of Dark Habitats. UNEP(DEPI)/MED WG. 431/Inf.12. http://rua.ua.es/dspace/bitstream/10045/70462/1/Dark_Habitats_wg_431_inf_12_eng.pdf

Althaus, F., Williams, A., Schlacher, T., Kloser, R., Green, M., Barker, B., Bax, N., Brodie, P., SchlacherHoenlinger, M. (2009). Impacts of bottom trawling on deep-coral ecosystems of seamounts are longlasting. Marine Ecology Progress Series, 397, 279-294. https://doi.org/10.3354/meps08248

Ambroso, S., Gori, A., Dominguez-Carrió, C., Gili, J.M., Berganzo, E., Teixidó, N., Greenacre, M. Rossi, S. (2013). Spatial distribution patterns of the soft corals Alcyonium acaule and Alcyonium palmatum in coastal bottoms (Cap de Creus, northwestern Mediterranean Sea). Marine Biology, 160(12), 3059-3070. https://doi.org/10.1007/s00227-013-2295-4

Angeletti, L., Taviani, M., Canese, S., Foglini, F., Mastrototaro, F., Argnani, A., Trincardi, F., Bakran-Petricioli, T., Ceregato, A., Chimienti, G., Macic, V. (2014). New deep-water cnidarian sites in the southern Adriatic Sea. Mediterranean Marine Science, 2, 263-273. 
Anscombe, F. J. and Glynn, W. J. (1983). Distribution of the kurtosis statistic b 2 for normal samples. Biometrika, 70(1), 227-234. https://doi.org/10.2307/2335960

Armstrong, C. W., Foley, N. S., Kahui, V., and Grehan, A. (2014). Cold water coral reef management from an ecosystem service perspective. Marine Policy, 50, 126-134. https://doi.org/10.1016/j.marpol.2014.05.016

Arnaud-Haond, S., Van den Beld, I.M.J., Becheler, R., Orejas, C., Menot, L., Frank, N., Grehan, A., and Bourillet, J.F. (2017). Two "pillars" of cold-water coral reefs along Atlantic European margins: prevalent association of Madrepora oculata with Lophelia pertusa, from reef to colony scale. Deep Sea Research Part I: Topical Studies in Oceanography, 145, 110-119. https://doi.org/10.1016/j.dsr2.2015.07.013

Bargain, A., Marchese, F., Savini, A., Taviani, M., and Fabri, M. C. (2017). Santa Maria di Leuca Province (Mediterranean Sea): Identification of suitable mounds for cold-water coral settlement using geomorphometric proxies and Maxent methods. Frontiers in Marine Science, 4, 338. https://doi.org/10.3389/fmars.2017.00338

Bo, M., Canese, S., and Bavestrello, G. (2014a). Discovering Mediterranean black coral forests: Parantipathes larix (Anthozoa: Hexacorallia) in the Tuscan Archipelago, Italy. Italian Journal of Zoology, 81(1), 112125. https://doi.org/10.1080/11250003.2013.859750

Bo, M., Cerrano, C., Canese, S., Salvati, E., Angiolillo, M., Santangelo, G., and Bavestrello, G. (2014b). The coral assemblages of an off-shore deep Mediterranean rocky bank (NW Sicily, Italy). Marine Ecology, 35(3), 332-342. https://doi.org/10.1111/maec.12089

Bo, M., Bavestrello, G., Angiolillo, M., Calcagnile, L., Canese, S., Cannas, R., Cau, A., D'Elia, M., D'Oriano, F., Follesa, M.C., and Quarta, G. (2015). Persistence of pristine deep-sea coral gardens in the Mediterranean Sea (SW Sardinia). PLoS One, 10(3), e0119393. https://doi.org/10.1371/journal.pone.0119393

Bo M., Barucca M., Biscotti M.A., Brugler M.R., Canapa A., Canese S., Lo Iacono C., Opresko, D.M., and Bavestrello G. (2018). Phylogenetic relationships of Mediterranean black corals (Cnidaria: Anthozoa: Hexacorallia) and implications for classification within the order Antipatharia. Invertebrate Systematics, accepted. https://doi.org/10.1071/IS17043

Buhl-Mortensen, L., Vanreusel, A., Gooday, A.J., Levin, L.A., Priede, I.G., Buhl-Mortensen, P., Gheerardyn, H., King, N.J., and Raes, M. (2010). Biological structures as a source of habitat heterogeneity and biodiversity on the deep ocean margins. Marine Ecology, 31(1), 21-50. https://doi.org/10.1111/j.1439-0485.2010.00359.x

Buhl-Mortensen, L., Serigstad, B., Buhl-Mortensen, P., Olsen, M., Ostrowski, M., Blazewicz-Paszkowycz, M., and Appoh, E. (2017). First observations of the structure and megafaunal community of a large Lophelia reef on the Ghanaian shelf (the Gulf of Guinea). Deep Sea Research Part II: Topical Studies in Oceanography, 137, 148-156. https://doi.org/10.1016/j.dsr2.2016.06.007

Bullimore, R.D., Foster, N.L., and Howell, K.L. (2013). Coral-characterized benthic assemblages of the deep Northeast Atlantic: defining "Coral Gardens" to support future habitat mapping efforts. ICES Journal of Marine Science, 70(3), 511-522. https://doi.org/10.1093/icesjms/fss195

Cau, A., Follesa, M.C., Moccia, D., Alvito, A., Bo, M., Angiolillo, M., Canese, S., Paliaga, E.M., Orrù, P.E., Sacco, F., and Cannas, R. (2015). Deepwater corals biodiversity along roche du large ecosystems with different habitat complexity along the south Sardinia continental margin (CW Mediterranean Sea). Marine Biology, 162(9), 1865-1878. https://doi.org/10.1007/s00227-015-2718-5

Chambers, J.M., Hastie, T.J., et al. (1992). Statistical models in S. Wadsworth \& Brooks/Cole Advanced Books and Software Pacific Grove, CA.

Coiras, E., Lo Iacono, C., Gràcia, E., Danobeitia, J., and Sanz, J. L. (2011). Automatic segmentation of multibeam data for predictive mapping of benthic habitats on the Chella Seamount (North-Eastern Alboran Sea, Western Mediterranean). IEEE Journal of Selected Topics in Applied Earth Observations and Remote 
Sensing, 4(4), 809-813.

https://doi.org/10.1109/JSTARS.2011.2123874

Comas, M. and Pinheiro, L.M. (2010). The Melilla carbonate mounds: do deep-water coral mounds count on seeping fluids in the Alboran Sea? Rapp. Comm. int. Mer Médit., 39, 16.

Corbera, G., Lo Iacono, C., Gracia, E., Grinyó, J., Pierdomenico, M., Huvenne, V.A., Aguilar, R., and Gili, J. M. (2017). Cold-water coral assemblages on the Cabliers Mound (Alboran Sea, Western Mediterranean): Diversity and structure. European Coral Reef Symposium, Oxford.

Costello, M.J., McCrea, M., Freiwald, A., Lundälv, T., Jonsson, L., Bett, B.J., van Weering, T.C., de Haas, H., Roberts, J. M., and Allen, D. (2005). Role of cold-water Lophelia pertusa coral reefs as fish habitat in the NE Atlantic. In Cold-water corals and ecosystems, Springer, pp. 771-805.

Cyr, F., Haren, H., Mienis, F., Duineveld, G., and Bourgault, D. (2016). On the influence of cold-water coral mound size on flow hydrodynamics, and vice versa. Geophysical Research Letters, 43(2), 775-783. https://doi.org/10.1002/2015GL067038

Davies, A.J., Wisshak, M., Orr, J.C. and Roberts, J.M. (2008). Predicting suitable habitat for the cold-water coral Lophelia pertusa (Scleractinia). Deep Sea Research Part I: Oceanographic Research Papers, 55(8), 1048-1062. https://doi.org/10.1016/j.dsr.2008.04.010

Davies, A.J., Duineveld, G.C., Lavaleye, M.S., Bergman, M.J., van Haren, H., and Roberts, J. M. (2009). Downwelling and deep-water bottom currents as food supply mechanisms to the cold-water coral Lophelia pertusa (Scleractinia) at the Mingulay Reef Complex. Limnology and Oceanography, 54(2), 620-629. https://doi.org/10.4319/lo.2009.54.2.0620

Davies, A.J. and Guinotte, J.M., 2011. Global habitat suitability for framework-forming cold-water corals. PloS One, 6(4), e18483. https://doi.org/10.1371/journal.pone.0018483

Davies, J., Guillaumont, B., Tempera, F., Vertino, A., Beuck, L., Ólafsdóttir, S., Smith, C., Fosså, J., Van den Beld, I., Savini, A., and Rengstorf, A. (2017). A new classification scheme of european cold-water coral habitats: implications for ecosystem-based management of the deep sea. Deep Sea Research Part II: Topical Studies in Oceanography, 145, 102-109. https://doi.org/10.1016/j.dsr2.2017.04.014

De Clippele, L. H., Huvenne, V. A. I., Orejas, C., Lundälv, T., Fox, A., Hennige, S. J., and Roberts, J. M. (2018). The effect of local hydrodynamics on the spatial extent and morphology of cold-water coral habitats at Tisler Reef, Norway. Coral Reefs, 37(1), 253-266. https://doi.org/10.1007/s00338-017-1653-y

De la Torriente, A., Serrano, A., Fernández-Salas, L., García, M., and Aguilar, R. (2018). Identifying epibenthic habitats on the Seco de los Olivos Seamount: Species assemblages and environmental characteristics. Deep Sea Research Part I: Oceanographic Research Papers, 135, 9-22. https://doi.org/10.1016/j.dsr.2018.03.015

De Mol, L., Van Rooij, D., Pirlet, H., Greinert, J., Frank, N., Quemmerais, F., and Henriet, J.-P. (2011). Coldwater coral habitats in the Penmarc'h and Guilvinec Canyons (Bay of Biscay): Deep-water versus shallowwater settings. Marine Geology, 282(1), 40-52. https://doi.org/10.1016/j.margeo.2010.04.011

Deval, M.C., Kebapçığlu, T., Güven, O. and Olguner, M.T. (2018). Population pattern and dynamics of the Bluemouth Helicolenus dactylopterus (Delaroche, 1809) in the eastern Mediterranean Sea. Journal of Applied Ichthyology, 34(3), 568-580. https://doi.org/10.1111/jai.13613

Dodds, L., Roberts, J., Taylor, A., and Marubini, F. (2007). Metabolic tolerance of the cold-water coral Lophelia pertusa (Scleractinia) to temperature and dissolved oxygen change. Journal of Experimental Marine Biology and Ecology, 349(2), 205-214. https://doi.org/10.1016/j.jembe.2007.05.013

Duggen, S., Hoernle, K., van den Bogaard, P., and Harris, C. (2004). Magmatic evolution of the Alboran region: the role of subduction in forming the western Mediterranean and causing the Messinian Salinity Crisis. Earth and Planetary Science Letters, 218(1), 91-108. https://doi.org/10.1016/S0012-821X(03)00632-0 
Duineveld, G.C., Lavaleye, M.S., and Berghuis, E.M. (2004). Particle flux and food supply to a seamount coldwater coral community (Galicia Bank, NW Spain). Marine Ecology Progress Series, 277, 13-23. https://doi.org/10.3354/meps277013

Duineveld, G.C., Jeffreys, R.M., Lavaleye, M.S., Davies, A.J., Bergman, M.J., Watmough, T., and Witbaard, R. (2012). Spatial and tidal variation in food supply to shallow cold-water coral reefs of the Mingulay Reef complex (Outer Hebrides, Scotland). Marine Ecology Progress Series, 444, 97-115. https://doi.org/10.3354/meps09430

Dullo, W.-C., Flogel, S., and Rüggeberg, A. (2008). Cold-water coral growth in relation to the hydrography of the Celtic and Nordic European continental margin. Marine Ecology Progress Series, 371, 165-176. https://doi.org/10.3354/meps07623

Fabri, M.-C. and Pedel, L. (2012). Biocénoses des fonds durs du bathyal et de l'abyssal/SRM MO. Technical report, IFREMER.

Fabri, M.-C., Pedel, L., Beuck, L., Galgani, F., Hebbeln, D., and Freiwald, A. (2014). Megafauna of vulnerable marine ecosystems in French Mediterranean submarine canyons: Spatial distribution and anthropogenic impacts. Deep Sea Research Part II: Topical Studies in Oceanography, 104, 184-207. https://doi.org/10.1016/j.dsr2.2013.06.016

Fabri, M.-C., Bargain, A., Pairaud, I., Pedel, L., and Taupier-Letage, I. (2017). Cold-water coral ecosystems in Cassidaigne Canyon: An assessment of their environmental living conditions. Deep Sea Research Part II: Topical Studies in Oceanography, 137, 436-453. https://doi.org/10.1016/j.dsr2.2016.06.006

Fanelli, E., Delbono, I., Ivaldi, R., Pratellesi, M., Cocito, S., and Peirano, A. (2017). Cold-water coral Madrepora oculata in the eastern Ligurian Sea (NW Mediterranean): Historical and recent findings. Aquatic Conservation: Marine and Freshwater Ecosystems, 27(5), 965-975. https://doi.org/10.1002/aqc. 2751

FAO. (2009). International guidelines for the management of deep-sea fisheries in the high seas. Technical report, FAO, Rome.

Fink, H. G., Wienberg, C., De Pol-Holz, R., Wintersteller, P., and Hebbeln, D. (2013). Cold-water coral growth in the Alboran Sea related to high productivity during the Late Pleistocene and Holocene. Marine Geology, 339, 71-82. https://doi.org/10.1016/j.margeo.2013.04.009

Fosså, J., Mortensen, P., and Furevik, D. (2002). The deep-water coral Lophelia pertusa in Norwegian waters: distribution and fishery impacts. Hydrobiologia, 471(1-3), 1-12. https://doi.org/10.1023/A:1016504430684

Freiwald, A., Fosså, J. H., Grehan, A., Koslow, T., and Roberts, J. M. (2004). Cold-water coral reefs. UNEPWCMC, Cambridge, UK.

Freiwald, A., Beuck, L., Rüggeberg, A., Taviani, M., Hebbeln, D., and R/V Meteor Cruise M70-1 participants (2009). The white coral community in the central Mediterranean Sea revealed by ROV surveys. Oceanography, 22(1), 58-74. https://doi.org/10.5670/oceanog.2009.06

García Lafuente, J., Cano, N., Vargas, M., Rubín, J.P., and Hernández-Guerra, A. (1998). Evolution of the alboran sea hydrographic structures during july 1993. Deep Sea Research Part I: Oceanographic Research Papers, 45(1), 39-65. https://doi.org/10.1016/S0967-0637(97)00216-1

GFCM. (2009). Criteria for the identification of sensitive habitats of relevance for the management of priority species (General Fisheries Commission for the Mediterranean). Malaga. p, 3.

Gómez de la Peña, L., Ranero, C.R., and Gràcia, E. (2018). The crustal domains of the Alboran Basin (western Mediterranean). Tectonics, 34, 1516-1543.

Gori, A., Rossi, S., Berganzo, E., Pretus, J.L., Dale, M. R., and Gili, J.-M. (2011). Spatial distribution patterns of the gorgonians Eunicella singularis, Paramuricea clavata, and Leptogorgia sarmentosa (Cape of Creus, Northwestern Mediterranean Sea). Marine Biology, 158(1), 143-158. https://doi.org/10.1007/s00227-010-1548-8

Gori, A., Orejas, C., Madurell, T., Bramanti, L., Martins, M., Quintanilla, E., Marti-Puig, P., Iacono, C.L., Puig, P., Requena, S., and Greenacre, M. (2013). Bathymetrical distribution and size structure of cold-water coral populations in the Cap de Creus and Lacaze-Duthiers canyons (northwestern Mediterranean). Biogeosciences, 10(3), 2049-2060. https://doi.org/10.5194/bg-10-2049-2013 
Gori, A., Bavestrello, G., Grinyó, J., Dominguez-Carrió, C., Ambroso, S., and Bo, M. (2017). Animal Forests in Deep Coastal Bottoms and Continental Shelf of the Mediterranean Sea. In: Marine Animal Forests, Springer, pp. 1-27.

Gràcia, E., Pallàs, R., Soto, J.I., Comas, M., Moreno, X., Masana, E., Santanach, P., Diez, S., García, M., Dañobeitia, J.J., and HITS Team. (2006). Active Faulting offshore SE Spain (Alboran Sea): Implications for earthquake hazard assessment in the Southern Iberian Margin. Earth Planetary Science Letters, 241, 734-749. https://doi.org/10.1016/j.epsl.2005.11.009

Gràcia, E., Bartolomé, R., Lo Iacono, C., Moreno, X., Stich, D., Martínez-Diaz, J.J., Bozzano, G., MartinezLoriente, S., Perea, H., Masana, E., Dañobeitia, J.J., Tello, O., Sanz, J.L., Carreño, E., and EVENT-SHELF team. (2012). Acoustic and seismic imaging of the active Adra Fault (NE Alboran Sea): In search for the source of the 1910 Adra Earthquake. Natural Hazards and Earth System Sciences, 12, 3255-3267. https://doi.org/10.5194/nhess-12-3255-2012

Greenacre, M. and Primicerio, R. (2013). Measures of distance between samples: noneuclidean. Multivariate analysis of ecological data, 5-1.

Grevemeyer, I., Gràcia, E., Villaseñor, A., Leuchters, W., and Watts, A.B. (2015). Seismicity and active tectonics in the Alboran Sea, Western Mediterranean: constraints from an offshore-onshore seismological network and swath bathymetry data. Journal of Geophysic Research - Solid Earth, 120, 8348-8365. https://doi.org/10.1002/2015JB012073

Grinyó, J., Gori, A., Ambroso, S., Purroy, A., Calatayud, C., Dominguez-Carrió, C., Coppari, M., Iacono, C.L., López-González, P.J., and Gili, J.-M. (2016). Diversity, distribution and population size structure of deep Mediterranean gorgonian assemblages (Menorca Channel, Western Mediterranean Sea). Progress in Oceanography, 145, 42-56. https://doi.org/10.1016/j.pocean.2016.05.001

Grinyó, J., Gori, A., Greenacre, M., Requena, S., Canepa, A., Iacono, C.L., Ambroso, S., Purroy, A., and Gili, J.-M. (2018). Megabenthic assemblages in the continental shelf edge and upper slope of the Menorca Channel, Western Mediterranean Sea. Progress in Oceanography, 162, 40-51. https://doi.org/10.1016/j.pocean.2018.02.002

Hebbeln, D. (2009). Report and preliminary results of R/V POSEIDON Cruise 385 [POS385]" Cold-water corals of the Alboran Sea (western Mediterranean Sea)", Faro-Toulon, 29.5.-16.6. 2009. Technical Report 273, Universität Bremen.

Hebbeln, D., Wienberg, C., Wintersteller, P., Freiwald, A., Becker, M., Beuck, L., Dullo, W. C., Eberli, G.P., Glogowski, S., Matos, L., and Forster, N. (2014). Environmental forcing of the Campeche cold-water coral province, southern Gulf of Mexico. Biogeosciences, 11, 1799-1815. https://doi.org/10.5194/bg-11-1799-2014

Hebbeln, D. and Wienberg, C. (2016). The east Melilla cold-water coral province in the Alboran Sea. Rapp. Comm. int. Mer Médit., 41, 25.

Henry, L.-A. and Roberts, J.M. (2007). Biodiversity and ecological composition of macrobenthos on cold-water coral mounds and adjacent off-mound habitat in the bathyal Porcupine Seabight, NE Atlantic. Deep Sea Research Part I: Oceanographic Research Papers, 54(4), 654-672. https://doi.org/10.1016/j.dsr.2007.01.005

Hovland, M. and Risk, M. (2003). Do norwegian deep-water coral reefs rely on seeping fluids? Marine Geology, 198(1-2), 83-96. https://doi.org/10.1016/S0025-3227(03)00096-3

Huvenne, V.A.I., Beyer, A., de Haas, H., Dekindt, K., Henriet, J.P., Kozachenko, M., Olu-Le Roy, K., Wheeler, A.J., and the TOBI/Pelagia 197 and CARACOLE cruise participants. (2005). The seabed appearance of different coral bank provinces in the Porcupine Seabight, NE Atlantic: results from sidescan sonar and ROV seabed mapping. In: Freiwald, A., Roberts, J.M. (Eds.). Cold-water corals and ecosystems, SpringerVerlag, Heidelberg, pp. 535-569. https://doi.org/10.1007/3-540-27673-4_27

Huvenne, V.A., Tyler, P.A., Masson, D.G., Fisher, E.H., Hauton, C., Hühnerbach, V., Le Bas, T.P., and Wolff, G.A. (2011). A picture on the wall: innovative mapping reveals cold-water coral refuge in submarine canyon. PloS One, 6(12), e28755. https://doi.org/10.1371/journal.pone.0028755

Ingrassia, M., Macelloni, L., Bosman, A., Chiocci, F., Cerrano, C., and Martorelli, E. (2016). Black coral (Anthozoa, Antipatharia) forest near the western Pontine Islands (Tyrrhenian Sea). Marine Biodiversity, 
46(1), 285-290.

https://doi.org/10.1007/s12526-015-0315-y

Jones, C. G., Lawton, J. H., and Shachak, M. (1994). Organisms as ecosystem engineers. Oikos, 69, 373-386. https://doi.org/10.2307/3545850

Kano, A., Ferdelman, T.G., Williams, T., Henriet, J.-P., Ishikawa, T., Kawagoe, N., Takashima, C., Kakizaki, Y., Abe, K., Sakai, S., and Browning, E. L. (2007). Age constraints on the origin and growth history of a deep-water coral mound in the northeast Atlantic drilled during Integrated Ocean Drilling Program Expedition 307. Geology, 35(11), 1051-1054. https://doi.org/10.1130/G23917A.1

Khripounoff, A., Caprais, J.C., Decker, C., Le Bruchec, J., Noel, P. and Husson, B. (2017). Respiration of bivalves from three different deep-sea areas: Cold seeps, hydrothermal vents and organic carbon-rich sediments. Deep Sea Research Part II: Topical Studies in Oceanography, 142, 233-243. https://doi.org/10.1016/j.dsr2.2016.05.023

Komsta, L. and Novomestky, F. (2012). Moments: Moments, cumulants, skewness, kurtosis and related tests [Computer Software]. R package version 0.13.

Koslow, J. A., Gowlett-Holmes, K., Lowry, J. K., O'Hara, T., Poore, G. C. B., and Williams, A. (2001). Seamount benthic macrofauna off southern Tasmania: community structure and impacts of trawling. Marine Ecology Progress Series, 213, 111-125. https://doi.org/10.3354/meps213111

Lastras, G., Canals, M., Ballesteros, E., Gili, J.-M., and Sanchez-Vidal, A. (2016). Cold-water corals and anthropogenic impacts in La Fonera submarine canyon head, Northwestern Mediterranean Sea. PloS One, 11(5), e0155729. https://doi.org/10.1371/journal.pone.0155729

Le Bas, T. (2016). RSOBIA-a new OBIA toolbar and toolbox in arcmap 10. $\mathrm{x}$ for segmentation and classification. GEOBIA 2016: Solutions and synergies.

Lim, A., Wheeler, A.J. and Arnaubec, A. (2017). High-resolution facies zonation within a cold-water coral mound: The case of the Piddington Mound, Porcupine Seabight, NE Atlantic. Marine Geology, 390, 120130. https://doi.org/10.1016/j.margeo.2017.06.009

Lo Iacono, C., Gràcia, E., Diez, S., Bozzano, G., Moreno, X., Dañobeitia, J.J., and Alonso, B., (2008). Seafloor characterization and backscatter variability of the Almería Margin (Alboran Sea, SW Mediterranean) based on high-resolution acoustic data. Marine Geology, 250, 1-18. https://doi.org/10.1016/j.margeo.2007.11.004

Lo Iacono, C., Gràcia, E., Bartolomé, R., Coiras, E., Dañobeitia, J.J., and Acosta, J. (2012). Habitats of the Chella Bank, Eastern Alboran Sea (Western Mediterranean). In Seafloor Geomorphology as Benthic Habitat, Elsevier, pp. 681-690. https://doi.org/10.1016/B978-0-12-385140-6.00049-9

Lo Iacono, C., Gràcia, E., Ranero, C.R., Emelianov, M., Huvenne, V.A., Bartolomé, R., Booth-Rea, G., Prades, J., Ambroso, S., Domínguez, C., and Grinyó. (2014). The West Melilla cold water coral mounds, Eastern Alboran Sea: Morphological characterization and environmental context. Deep Sea Research Part II: Topical Studies in Oceanography, 99, 316-326. https://doi.org/10.1016/j.dsr2.2013.07.006

Lo Iacono, C. (2016). Living reefs and CWC mounds in the Alboran Sea (Western Mediterranean): Holocene evolution and present day conditions. 6th International Symposium on Deep-Sea Corals, Boston. O.

Lo Iacono, C., Robert, K., Gonzalez-Villanueva, R., Gori, A., Gili, J. M., and Orejas, C. (2018a). Predicting cold-water coral distribution in the Cap de Creus Canyon (NW Mediterranean): Implications for marine conservation planning. Progress in Oceanography, 169, 169-180. https://doi.org/10.1016/j.pocean.2018.02.012

Lo Iacono, C., Savini, A., and Basso, D. (2018b). Cold-water carbonate bioconstructions. In Submarine Geomorphology, Springer, pp. 425-455. https://doi.org/10.1007/978-3-319-57852-1_22

Lo Iacono, C., Savini, A., Huvenne, V. A., and Gràcia E. (2018c). Habitat mapping of Cold Water Corals in the Mediterranean Sea. In: Past, present and future: Mediterranean Cold Water Corals. Springer.

Lomolino, M. V., Riddle, B. R., Brown, J. H., and Brown, J. H. (2006). Biogeography (No. QH84 L65 2006). Sunderland, MA: Sinauer Associates. 
Maier, C., Hegeman, J., Weinbauer, M., and Gattuso, J.-P. (2009). Calcification of the cold-water coral Lophelia pertusa, under ambient and reduced $\mathrm{pH}$. Biogeosciences, 6(8), 1671-1680. https://doi.org/10.5194/bg-6-1671-2009

Marsh, L., Copley, J.T., Huvenne, V.A., Linse, K., Reid, W.D., Rogers, A.D., Sweeting, C. J., and Tyler, P.A. (2012). Microdistribution of faunal assemblages at deep-sea hydrothermal vents in the Southern Ocean. PLoS One, 7(10), e48348. https://doi.org/10.1371/journal.pone.0048348

Mastrototaro, F., D'Onghia, G., Corriero, G., Matarrese, A., Maiorano, P., Panetta, P., Gherardi, M., Longo, C., Rosso, A., Sciuto, F., and Sanfilippo, R. (2010). Biodiversity of the white coral bank off Cape Santa Maria di Leuca (Mediterranean Sea): An update. Deep Sea Research Part II: Topical Studies in Oceanography, 57(5), 412-430. https://doi.org/10.1016/j.dsr2.2009.08.021

Matos, L., Wienberg, C., Titschack, J., Schmiedl, G., Frank, N., Abrantes, F., Cunha, M.R. and Hebbeln, D. (2017). Coral mound development at the Campeche cold-water coral province, southern Gulf of Mexico: Implications of Antarctic Intermediate Water increased influence during interglacials. Marine Geology, 392, 53-65. https://doi.org/10.1016/j.margeo.2017.08.012

Mazzini, A., Akhmetzhanov, A., Monteys, X., and Ivanov, M. (2012). The Porcupine Bank Canyon coral mounds: oceanographic and topographic steering of deep-water carbonate mound development and associated phosphatic deposition. Geo-Marine Letters, 32(3), 205-225. https://doi.org/10.1007/s00367-011-0257-8

Mienis, F., De Stigter, H. C., White, M., Duineveld, G., De Haas, H., and Van Weering, T. C. E. (2007). Hydrodynamic controls on cold-water coral growth and carbonate-mound development at the SW and SE Rockall Trough Margin, NE Atlantic Ocean. Deep Sea Research Part I: Oceanographic Research Papers, 54(9), 1655-1674. https://doi.org/10.1016/j.dsr.2007.05.013

Mienis, F., De Stigter, H., De Haas, H., Van der Land, C., and Van Weering, T. (2012). Hydrodynamic conditions in a cold-water coral mound area on the Renard Ridge, southern Gulf of Cadiz. Journal of Marine Systems, 96, 61-71. https://doi.org/10.1016/j.jmarsys.2012.02.002

Mienis F., Duineveld G.C., Davies A.J., Lavaleye M.M.S., Ross S. W., Seim H., Bane J., Van Haren H, Bergman M.J.N., De Haas H., Brooke S., and Van Weering T. (2014). Cold-water coral growth under extreme environmental conditions, the Cape Lookout area, NW Atlantic. Biogeosciences, 11, 2543-2560. https://doi.org/10.5194/bg-11-2543-2014

Millot, C. (1999). Circulation in the western Mediterranean Sea. Journal of Marine Systems, 20(1), 423-442. https://doi.org/10.1016/S0924-7963(98)00078-5

Millot, C. (2009). Another description of the Mediterranean Sea outflow. Progress in Oceanography, 82(2), 101-124. https://doi.org/10.1016/j.pocean.2009.04.016

Moreno, X., Gràcia, E., Bartolomé, R., Martínez-Loriente, S., Perea, H., Goméz De La Peña, L., Lo Iacono, C., Piñero, E., Pallàs, R., Masana, E., and Dañobeitia, J.J. (2016). Seismostratigraphy and tectonic architecture of the Carboneras Fault offshore based on multiscale seismic imaging: Implications for the Neogene evolution of the NE Alboran Sea. Tectonophysics, 689, 115-132.

Mortensen, P.B., Hovland, M., Brattegard, T., and Farestveit, R. (1995). Deep water bioherms of the scleractinian coral Lophelia pertusa (L.) at $64^{\circ} \mathrm{N}$ on the Norwegian shelf: structure and associated megafauna structure. Sarsia, 80(2), 145-158. https://doi.org/10.1080/00364827.1995.10413586

Mortensen, P.B., Hovland, T., Fosså, J.H. and Furevik, D.M., 2001. Distribution, abundance and size of Lophelia pertusa coral reefs in mid-Norway in relation to seabed characteristics. Journal of the Marine Biological Association of the United Kingdom, 81(4), 581-597. https://doi.org/10.1017/S002531540100426X

Mortensen, P.B., and Fosså, J.H. (2006). Species diversity and spatial distribution of invertebrates on deepwater Lophelia reefs in Norway. In Suzuki, Y.E.A., editor, Proceedings of the 10th International Coral Reef Symposium, pp. 1849-1860. 
Naumann, M.S., Orejas, C., and Ferrier-Pagès, C. (2014). Species-specific physiological response by the coldwater corals Lophelia pertusa and Madrepora oculata to variations within their natural temperature range. Deep Sea Research Part II: Topical Studies in Oceanography, 99, 36-41. https://doi.org/10.1016/j.dsr2.2013.05.025

Neves, B.M., Du Preez, C., and Edinger, E. (2014). Mapping coral and sponge habitats on a shelf-depth environment using multibeam sonar and ROV video observations: Learmonth Bank, northern British Columbia, Canada. Deep Sea Research Part II: Topical Studies in Oceanography, 99, 169-183. https://doi.org/10.1016/j.dsr2.2013.05.026

Oceana (2015). Expedition 2014 Balearic Islands Cabrera National Park and Mallorca Channel Seamounts. Technical report.

Oguz, T., Macias, D., Garcia-Lafuente, J., Pascual, A., and Tintore, J. (2014). Fueling plankton production by a meandering frontal jet: a case study for the Alboran Sea (Western Mediterranean). PLoS One, 9(11), e111482. https://doi.org/10.1371/journal.pone.0111482

Oksanen, J., Blanchet, F.G., Kindt, R., Legendre, P., Minchin, P.R., O'hara, R.B., Simpson, G.L., Solymos, P., Stevens, M.H.H., Wagner, H. and Oksanen, M.J. (2013). Package 'vegan'. Community ecology package, version, 2(9).

Oliver, W. A. (1968). Some aspects of colony development in corals. Journal of Paleontology, 42(S2), 16-34.

Opresko, D.M. (2009). Antipatharia (Cnidaria) of the Gulf of Mexico. Gulf of Mexico origin, waters, and biota, $1,359-363$.

Orejas, C., Gori, A., Lo Iacono, C., Puig, P., Gili, J.-M., Dale, M.R. (2009). Cold-water corals in the Cap de Creus canyon, northwestern Mediterranean: spatial distribution, density and anthropogenic impact. Marine Ecology Progress Series, 397, 37-51. https://doi.org/10.3354/meps08314

OSPAR Commision. (2008). OSPAR List of Threatened and/or Declining Species and Habitats. Available online at: https://www.ospar.org/work-areas/bdc/species-habitats/list-of-threatened-declining-specieshabitats. Accesed 21/05/2018.

Perea, H., Gràcia, E., Martínez-Loriente, S., Bartolome, R., Gómez De La Peña, L., De Mol, B., Moreno, X., Lo Iacono, C., Diez, S., Tello, O., Ballesteros, M., and Dañobeitia, J.J. (2017). Kinematic analysis of secondary faults within a distributed shear-zone reveals fault linkages and increased seismic hazard. Marine Geology, 399, 23-33. https://doi.org/10.1016/j.margeo.2018.02.002

Pierdomenico, M., Russo, T., Ambroso, S., Gori, A., Martorelli, E., D'Andrea, L., Gili, J.M. Chiocci, F. L. (2018). Effects of trawling activity on the bamboo-coral Isidella elongata and the sea pen Funiculina quadrangularis along the Gioia Canyon (Western Mediterranean, southern Tyrrhenian Sea). Progress in Oceanography. https://doi.org/10.1016/j.pocean.2018.02.019

Purser, A., Orejas, C., Gori, A., Tong, R., Unnithan, V., and Thomsen, L. (2013). Local variation in the distribution of benthic megafauna species associated with cold-water coral reefs on the Norwegian margin. Continental Shelf Research, 54, 37-51. https://doi.org/10.1016/j.csr.2012.12.013

R Core Team (2017). R: A language and environment for statistical computing. R Foundation for Statistical Computing, Vienna, Austria.

Remia, A. and Taviani, M. (2005). Shallow-buried Pleistocene Madrepora- dominated coral mounds on a muddy continental slope, Tuscan Archipelago, NE Tyrrhenian Sea. Facies, 50(3-4), 419-425. https://doi.org/10.1007/s10347-004-0029-2

Rice, J., Gjerde, K. M., Ardron, J., Arico, S., Cresswell, I., Escobar, E., ... and Vierros, M. (2011). Policy relevance of biogeographic classification for conservation and management of marine biodiversity beyond national jurisdiction, and the GOODS biogeographic classification. Ocean \& Coastal Management, 54(2), $110-122$. https://doi.org/10.1016/j.ocecoaman.2010.10.010

Roberts, J.M., Wheeler, A.J., and Freiwald, A. (2006). Reefs of the deep: the biology and geology of cold-water coral ecosystems. Science, 312(5773), 543-547. https://doi.org/10.1126/science.1119861 
Roberts, J. M., Henry, L. A., Long, D., and Hartley, J. P. (2008). Cold-water coral reef frameworks, megafaunal communities and evidence for coral carbonate mounds on the Hatton Bank, north east Atlantic. Facies, 54(3), 297-316. https://doi.org/10.1007/s10347-008-0140-X

Roberts, J. M., Davies, A. J., Henry, L. A., Dodds, L. A., Duineveld, G. C. A., Lavaleye, M. S. S., ... and Huvenne, V. A. I. (2009a). Mingulay reef complex: an interdisciplinary study of cold-water coral habitat, hydrography and biodiversity. Marine Ecology Progress Series, 397, 139-151. https://doi.org/10.3354/meps08112

Roberts, J.M., Wheeler, A., Freiwald, A. and Cairns, S. (2009b). Cold-water corals: the biology and geology of deep-sea coral habitats. Cambridge University Press. https://doi.org/10.1017/CBO9780511581588

Rogers, A.D. (1999). The biology of Lophelia pertusa (Linnaeus 1758) and other deep-water reef-forming corals and impacts from human activities. International Review of Hydrobiology, 84(4), 315-406. https://doi.org/10.1002/iroh.199900032

Rona, P., Guida, V., Scranton, M., Gong, D., Macelloni, L., Pierdomenico, M., Diercks, A.-R., Asper, V., and Haag, S. (2015). Hudson submarine canyon head offshore New York and New Jersey: A physical and geochemical investigation. Deep Sea Research Part II: Topical Studies in Oceanography, 121, 213-232. https://doi.org/10.1016/j.dsr2.2015.07.019

Ross, S. W. (2006). Review of distribution, habitats, and associated fauna of deep water coral reefs on the southeastern United States continental slope (North Carolina to Cape Canaveral, FL). Report to the South Atlantic Fishery Management Council, Charleston, SC.

Ross, S. W., and Nizinski, M. S. (2007). State of deep coral ecosystems in the US southeast region: Cape Hatteras to southeastern Florida. The State of Deep Coral Ecosystems of the United States, 233-270.

Ross, S. W., Rhode, M., and Brooke, S. (2017). Reprint of-Deep-sea coral and hardbottom habitats on the west Florida slope, eastern Gulf of Mexico. Deep Sea Research Part I: Oceanographic Research Papers, 127, 114-128. https://doi.org/10.1016/j.dsr.2017.08.008

Santín, A., Grinyó, J., Ambroso, S., Uriz, M.J., Gori, A., Dominguez-Carrió, C., and Gili, J.-M. (2017). Sponge assemblages on the deep Mediterranean continental shelf and slope (Menorca Channel, Western Mediterranean Sea). Deep Sea Research Part I: Oceanographic Research Papers, 131, 75-86. https://doi.org/10.1016/j.dsr.2017.11.003

Santín, A., Grinyó, J., Ambroso, S., Uriz, M. J., Dominguez-Carrió, C., and Gili, J. M. (2019). Distribution patterns and demographic trends of demosponges at the Menorca Channel (Northwestern Mediterranean Sea). Progress in Oceanography, 173, 9-25. https://doi.org/10.1016/j.pocean.2019.02.002

Sappington, J.M., Longshore, K.M. and Thompson, D.B. 2007. Quantifying landscape ruggedness for animal habitat analysis: a case study using bighorn sheep in the Mojave Desert. Journal of Wildlife Management, 71(5), 1419-1426. https://doi.org/10.2193/2005-723

Sartoretto, S., and Zibrowius, H. (2018). Note on new records of living Scleractinia and Gorgonaria between 1700 and $2200 \mathrm{~m}$ depth in the western Mediterranean Sea. Marine Biodiversity, 48(1), 689-694. https://doi.org/10.1007/s12526-017-0829-6

Savini, A. and Corselli, C. (2010). High-resolution bathymetry and acoustic geophysical data from Santa Maria di Leuca Cold Water Coral province (Northern Ionian Sea-Apulian continental slope). Deep Sea Research Part II: Topical Studies in Oceanography, 57(5-6), 326-344. https://doi.org/10.1016/j.dsr2.2009.08.014

Savini, A., Marchese, F., Verdicchio, G., and Vertino, A. (2016). Submarine slide to- pography and the distribution of vulnerable marine ecosystems: a case study in the Ionian Sea (Eastern Mediterranean). In Submarine Mass Movements and their Consequences, Springer, pp. 163-170. https://doi.org/10.1007/978-3-319-20979-1_16

Spakman, W, Chertova, M.V., van den Berg, A., and van Hinsbergen, D.J.J. (2018). Puzzling features of western Mediterranean tectonics explained by slab dragging. Nature Geoscience, 11, 211-216. https://doi.org/10.1038/s41561-018-0066-Z

Taviani, M., Remia, A., Corselli, C., Freiwald, A., Malinverno, E., Mastrototaro, F., Savini, A., and Tursi, A. (2005). First geo-marine survey of living cold-water Lophelia reefs in the Ionian Sea (Mediterranean 
basin). Facies, 50(3-4), 409-417.

https://doi.org/10.1007/s10347-004-0039-0

Taviani, M., Angeletti, L., Canese, S., Cannas, R., Cardone, F., Cau, A., Cau, A., Follesa, M. C., Marchese, F., Montagna, P., and Tessarolo, C. (2017). The "Sardinian cold-water coral province" in the context of the Mediterranean coral ecosystems. Deep Sea Research Part II: Topical Studies in Oceanography, 145, 6178. https://doi.org/10.1016/j.dsr2.2015.12.008

Tong, R., Purser, A., Unnithan, V., and Guinan, J. (2012). Multivariate statistical analysis of distribution of deep-water gorgonian corals in relation to seabed topography on the Norwegian margin. PLoS One, 7(8), e43534. https://doi.org/10.1371/journal.pone.0043534

Thresher, R., Althaus, F., Adkins, J., Gowlett-Holmes, K., Alderslade, P., Dowdney, J., Cho, W., Gagnon, A., Staples, D., McEnnulty, F., and Williams, A. (2014). Strong depth-related zonation of megabenthos on a rocky continental margin ( 700-4000 m) off southern Tasmania, Australia. PLoS One, 9(1), e85872. https://doi.org/10.1371/journal.pone.0085872

Van Rooij, D., Huvenne, V.A., Blamart, D., Henriet, J.P., Wheeler, A., and De Haas, H. (2009). The Enya mounds: a lost mound-drift competition. International Journal of Earth Sciences, 98(4), 849-863. https://doi.org/10.1007/s00531-007-0293-9

van Soest, R. W., van Duyl, F. C., Maier, C., Lavaleye, M. S., Beglinger, E. J., Tabachnick, K. R., ... and Muricy, G. (2007). Mass occurrence of Rossella nodastrella Topsent on bathyal coral reefs of Rockall Bank, W of Ireland (Lyssacinosida, Hexactinellida). Porifera Research: Biodiversity, Innovation and Sustainability. Museu Nacional, Rio de Janeiro, pp. 645-652.

Vertino, A., Savini, A., Rosso, A., Di Geronimo, I., Mastrototaro, F., Sanfilippo, R., Gay, G., and Etiope, G. (2010). Benthic habitat characterization and distribution from two representative sites of the deep-water SML Coral Province (Mediterranean). Deep Sea Research Part II: Topical Studies in Oceanography, 57(56), 380-396. https://doi.org/10.1016/j.dsr2.2009.08.023

Walbridge, S., Slocum, N., Pobuda, M. and Wright, D.J. (2018). Unified geomorphological analysis workflows with benthic terrain modeler. Geosciences, 8(3), 94 . https://doi.org/10.3390/geosciences8030094

Wienberg, C., and Titschack, J. (2017). Framework-forming scleractinian cold-water corals through space and time: a late Quaternary North Atlantic perspective. In: Rossi S., Bramanti L., Gori A., Orejas C. (eds) Marine Animal Forests. Springer, Cham, pp. 699-732. https://doi.org/10.1007/978-3-319-21012-4_16

Whittaker, R.J., Araújo, M.B., Jepson, P., Ladle, R.J., Watson, J.E. and Willis, K.J. (2005). Conservation biogeography: assessment and prospect. Diversity and distributions, 11(1), 3-23.

https://doi.org/10.1111/j.1366-9516.2005.00143.x

Würtz, M. and M. Rovere (eds) (2015). Atlas of the Mediterranean Seamounts and Seamount-like Structures. Gland, Switzerland and Málaga, Spain: IUCN. https://doi.org/10.2305/IUCN.CH.2015.07.en

Wynn, R.B., Huvenne, V.A., Le Bas, T.P., Murton, B.J., Connelly, D.P., Bett, B.J., Ruhl, H.A., Morris, K.J., Peakall, J., Parsons, D.R. and Sumner, E.J. (2014). Autonomous Underwater Vehicles (AUVs): Their past, present and future contributions to the advancement of marine geoscience. Marine Geology, 352, 451-468. https://doi.org/10.1016/j.margeo.2014.03.012

Zajac, R.N., Lewis, R.S., Poppe, L.J., Twichell, D.C., Vozarik, J., and DiGiacomo-Cohen, M.L. (2000). Relationships among sea-floor structure and benthic communities in Long Island Sound at regional and benthoscape scales. Journal of Coastal Research, 16, 627-640 

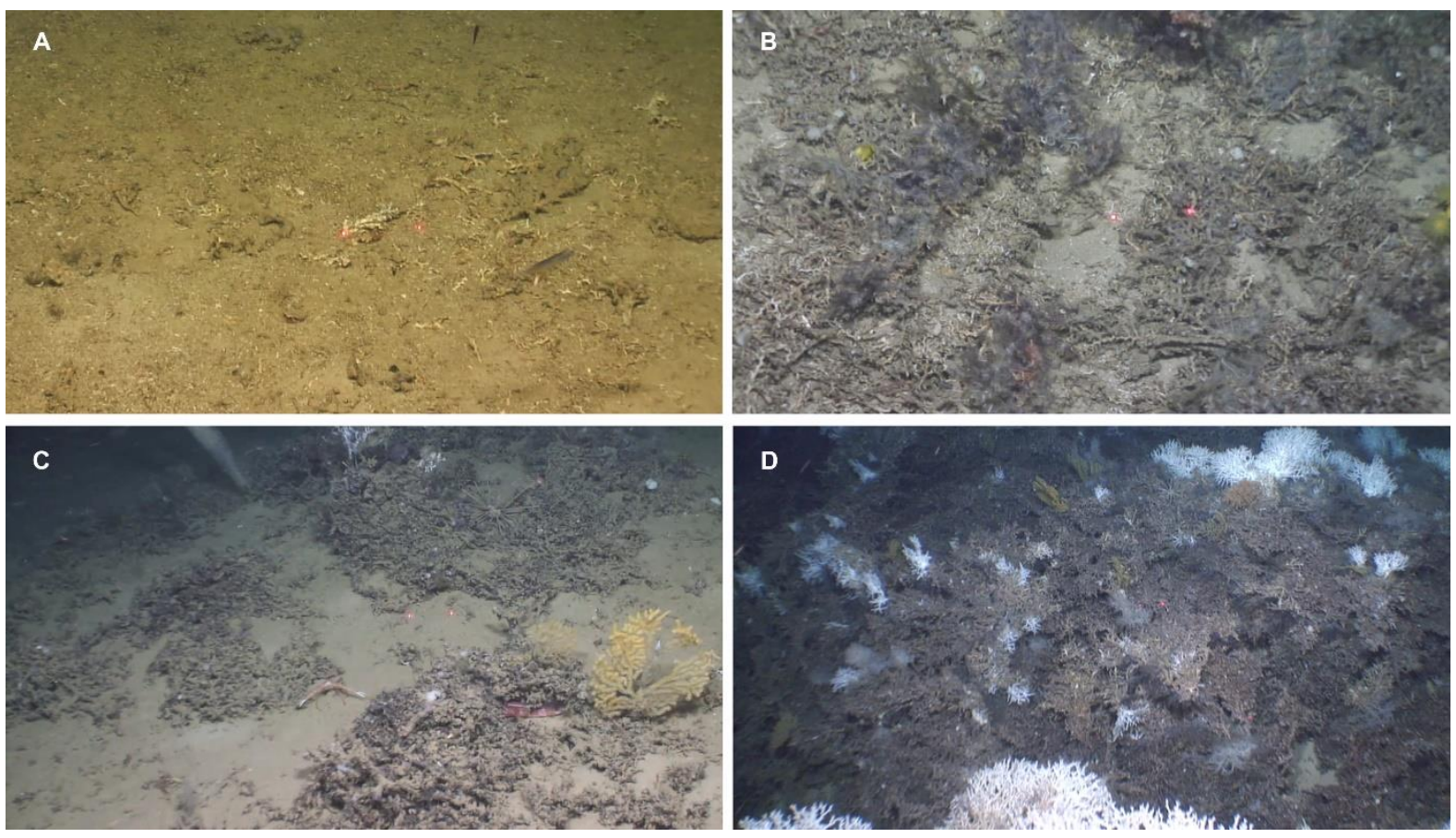

Figure S1. Substrate types observed on the Cabliers Coral Mound. Fine sands with coral rubble (A), coral rubble (B), coral framework with fine sands (C) and coral framework (D).
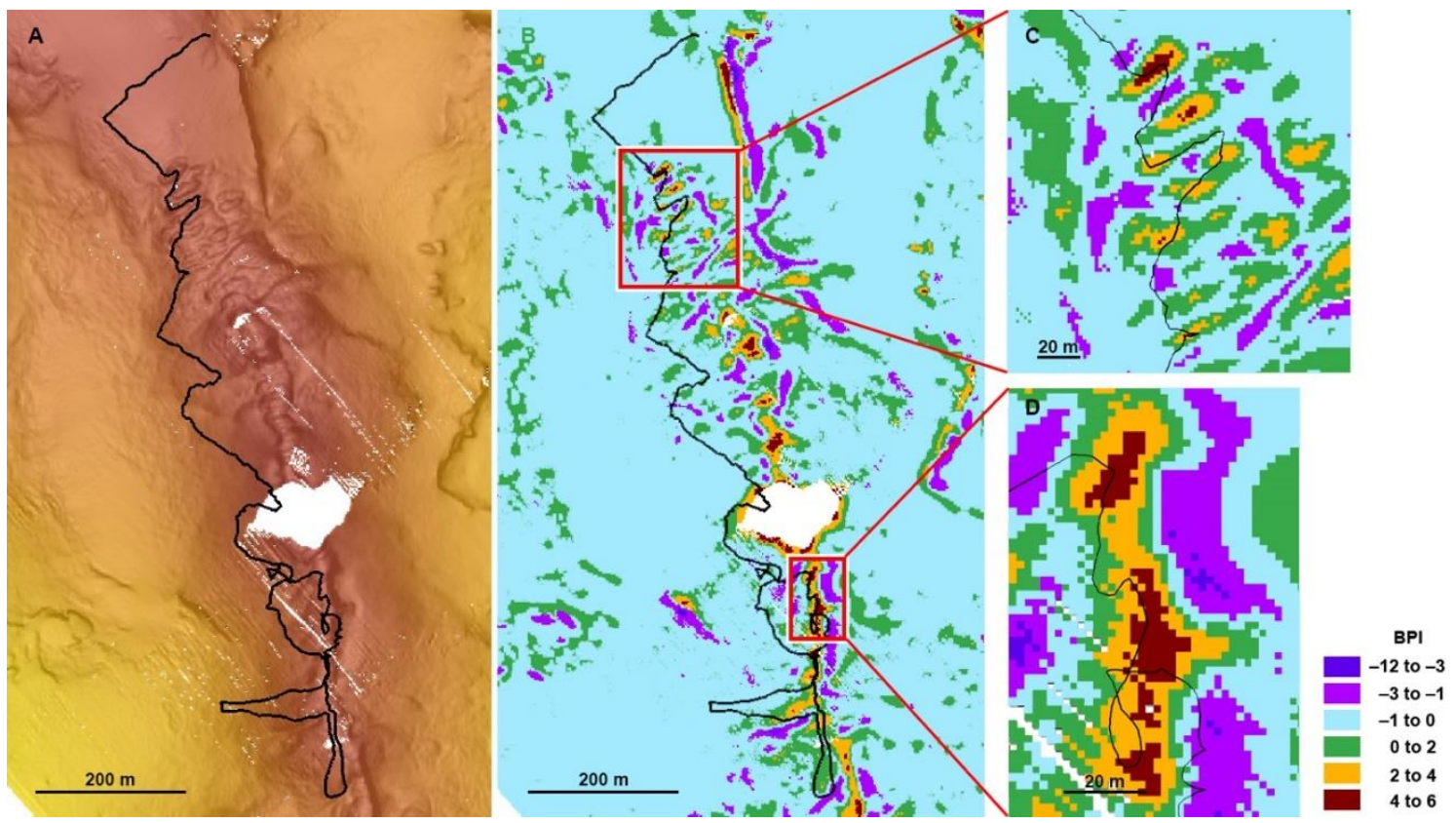

Figure S2. Map showing the Dive 1 ROV path (black line) on the AUV bathymetry (A) and the fine scale bathymetric position index (BPI; inner radius: $5 \mathrm{~m}$, outer radius: $10 \mathrm{~m}$ ) (B) used to identify the mini-mound like features located on the crest of the mound. Zooms from the red dashed boxes (C, D) show the areas where the ROV travelled over the crest of the mound. Dark and light purple represent negative elevation features (i.e. valleys, troughs); light blue and green indicate flat and gentle slopes; orange and brown denote positive elevation features (i.e. mini-mounds). Here the spearman rank correlation was used to assess the correlation between coral density and mini-mound occurrence. 
Table S1. Abundance of the species identified in each ROV Dive and total abundance for the whole study area.

\begin{tabular}{|c|c|c|c|c|c|}
\hline & & \multicolumn{2}{|c|}{ Northern Cabliers } & \multirow{2}{*}{$\begin{array}{r}\text { Southern Cabliers } \\
\text { Dive } 3 \\
\end{array}$} & \multirow[b]{2}{*}{ Total } \\
\hline & & Dive 1 & Dive 2 & & \\
\hline \multirow[t]{12}{*}{ Cnidaria } & Phanopathes rigida & 816 & 716 & 0 & 1532 \\
\hline & Acanthogorgia hirsuta & 345 & 228 & 918 & 1491 \\
\hline & Madrepora oculata & 967 & 178 & 15 & 1160 \\
\hline & Leiopathes glaberrima & 368 & 21 & 0 & 389 \\
\hline & Parantipathes larix & 97 & 31 & 234 & 362 \\
\hline & Lophelia pertusa & 84 & 27 & 2 & 113 \\
\hline & Dendrophyllia cornigera & 59 & 25 & 2 & 86 \\
\hline & Antipathes dichotoma & 30 & 29 & 0 & 59 \\
\hline & Cerianthus sp. & 0 & 0 & 13 & 13 \\
\hline & Chyronephtia mediterranea & 5 & 2 & 2 & 9 \\
\hline & Kophobelemnom sp. & 1 & 1 & 6 & 8 \\
\hline & Callogorgia verticillata & 1 & 0 & 0 & 1 \\
\hline \multirow[t]{7}{*}{ Porifera } & Pacastrella sp. & 413 & 244 & 10 & 667 \\
\hline & Asconema setubalense & 219 & 171 & 0 & 390 \\
\hline & Geodia sp. & 0 & 30 & 8 & 38 \\
\hline & Axinella infundibulum & 1 & 12 & 1 & 14 \\
\hline & Hamacantha falcula & 0 & 13 & 0 & 13 \\
\hline & White encrusting sponge & 0 & 8 & 0 & 8 \\
\hline & Yellow encrusting sponge & 0 & 2 & 0 & 2 \\
\hline \multirow[t]{7}{*}{ Echinodermata } & Cidaris cidaris & 186 & 116 & 68 & 370 \\
\hline & Echinus melo & 7 & 5 & 0 & 12 \\
\hline & Asteroidea 1 & 1 & 1 & 9 & 11 \\
\hline & Echinus acutus & 5 & 1 & 0 & 6 \\
\hline & Holothuroidea 1 & 3 & 2 & 1 & 6 \\
\hline & Asteroidea 2 & 0 & 0 & 4 & 4 \\
\hline & Holothuroidea 2 & 0 & 0 & 2 & 2 \\
\hline \multirow[t]{3}{*}{ Arthropoda } & Galatheoidea & 25 & 27 & 348 & 400 \\
\hline & Bathynectes sp. & 0 & 4 & 22 & 26 \\
\hline & Decapoda & 5 & 0 & 9 & 14 \\
\hline Mollusca & Ostreida & 0 & 12 & 0 & 12 \\
\hline \multirow[t]{12}{*}{ Chordata } & Helicolenus dactylopterus & 93 & 46 & 42 & 181 \\
\hline & Hoplostetus mediterraneus & 27 & 110 & 38 & 175 \\
\hline & Nezumia aequalis & 24 & 15 & 21 & 60 \\
\hline & Pagellus bogaraveo & 21 & 1 & 20 & 42 \\
\hline & Capros aper & 7 & 0 & 0 & 7 \\
\hline & Anthias anthias & 5 & 0 & 0 & 5 \\
\hline & Scorpaena scrofa & 3 & 2 & 0 & 5 \\
\hline & Pleuronectidae & 2 & 0 & 0 & 2 \\
\hline & Physcis blennoides & 2 & 0 & 0 & 2 \\
\hline & Conger conger & 0 & 0 & 1 & 1 \\
\hline & Scyliorhinus canicula & 0 & 1 & 1 & 2 \\
\hline & Unidentified fish & 1 & 21 & 15 & 37 \\
\hline
\end{tabular}


Table S2. Results of the CCA analysis implemented at different sampling unit sizes.

\begin{tabular}{ccccccc}
\hline SU size & SU N & $\begin{array}{c}\text { Total } \\
\text { inertia }\end{array}$ & $\begin{array}{c}\text { Constrained } \\
\text { inertia }\end{array}$ & $\begin{array}{c}\text { Unconstrained } \\
\text { inertia }\end{array}$ & $\begin{array}{c}\text { \% Inertia explained by } \\
\text { env. fact. }\end{array}$ & $\begin{array}{c}\mathbf{N}^{\circ} \text { of } \\
\text { assemblages }\end{array}$ \\
\hline 2 & 2159 & 8.6164 & 0.9363 & 7.6801 & 10.87 & 5 \\
4 & 739 & 6.3787 & 0.8853 & 5.4934 & 13.88 & 5 \\
10 & 349 & 4.0646 & 0.7633 & 3.3013 & 18.78 & 4 \\
20 & 215 & 2.9713 & 0.6927 & 2.2786 & 23.31 & 3 \\
\hline
\end{tabular}

$14 \overline{22}$ 